\title{
Review Article \\ Translational Research in Stem Cell Treatment of Neuromuscular Diseases
}

\author{
Hakan Orbay ${ }^{1}$ and Hiroshi Mizuno ${ }^{2}$ \\ ${ }^{1}$ Department of Radiology, University of Wisconsin, Madison, WI 53792, USA \\ ${ }^{2}$ Department of Plastic and Reconstructive Surgery, Juntendo University School of Medicine, Tokyo 1138421, Japan
}

Correspondence should be addressed to Hiroshi Mizuno; hmizuno@juntendo.ac.jp

Received 21 August 2012; Accepted 9 September 2012

Academic Editors: A. Chapel and F. Fagioli

Copyright (C) 2013 H. Orbay and H. Mizuno. This is an open access article distributed under the Creative Commons Attribution License, which permits unrestricted use, distribution, and reproduction in any medium, provided the original work is properly cited.

\begin{abstract}
Neuromuscular diseases are a heterogeneous group of diseases that lead to significant disability in effected individuals. Pharmacological treatments failed to provide any significant improvement to date. Recently, the introduction of stem cells into the field of health sciences raised the hopes for a new treatment for neuromuscular diseases. In theory, stem cells, owing to their multilineage differentiation capacity, could differentiate into myofibers and neurons and replace the degenerated cells leading to recovery of the patients. Results obtained from the preclinical studies supported this theory. However, clinical trials with stem cells could not meet the expectations mainly because of early mortality, limited migration, and differentiation of the implanted cells. Modification of the stem cells before implantation, such as introduction of deficient genes or commitment to a precursor cell line provided little improvement. The biggest barrier to overcome for a successful of stem cell treatment, which also should be the focus of the future studies, is to increase the functional integration of the donor cells with the recipient tissues. Understanding the underlying pathogenic mechanisms of the neuromuscular diseases is essential to achieve this goal.
\end{abstract}

\section{Introduction}

The term neuromuscular diseases define a wide range of conditions characterized by the weakness or wasting of the body muscles. Problems may primarily originate from the spinal cord, the peripheral nerves (neuropathies), the muscle fibers (myopathies), or the neuromuscular junction. Some of these diseases are hereditary, while others are acquired. The diagnosis is mainly done by clinical observation, electromyography, muscle biopsy, and in some instances molecular genetic studies. Some of the major types of neuromuscular diseases are amyotrophic lateral sclerosis (ALS), myasthenia gravis (MG), multiple sclerosis (MS), and muscular dystrophies (Duchenne's muscular dystrophy (DMD) and Becker's muscular dystrophy (BMD)). Despite the long lasting research on the pathogenesis and the molecular mechanisms of neuromuscular diseases, no satisfactory treatment has been offered yet for these diseases [1].

Stem cell research is relatively new in the medical field but holds a great potential for the treatment of a variety of diseases that remained untreatable so far. Stem cells are believed to exist in all tissues in human body and may be totipotent, pluripotent, or multipotent, depending on tissue type. Neuromuscular degeneration itself seems to promote proliferation, migration, and transdifferentiation of autologous stem cells. Production of neurotropic and growth factors and stimulation of the regenerative processes by stem cells have been demonstrated in neurodegenerative diseases [2]. Therefore, human skeletal muscle tissue and nerve tissue have a limited regeneration capacity via the muscle stem cells, also called satellite cells and nerve derived stem cells, respectively [3]. However, this regeneration capacity is not enough to reverse the pathological process in case of neuromuscular diseases. Following the discovery of multilineage plasticity of the stem cells that can be obtained in large numbers from easily accessible tissues, several attempts have been performed to treat neuromuscular diseases via the local or systemic injection of the stem cells. Despite the promising results obtained from in vitro studies, these attempts have yielded limited success in vivo as well as in clinical trials. 
This in part is due to the complexity of the microenvironment needed to ensure stem cell integration and function [3].

The aim of this paper is to summarize the translational research on the most common types of neuromuscular diseases.

\section{Anatomy of Neuromuscular Unit}

The formation of skeletal muscle begins during the fourth week of embryonic development by the rapid mitotic division of specialized mesodermal cells, termed myoblasts. By week nine of development, multinucleated skeletal muscle cells, termed muscle fibers, can be identified. By month five, the muscle fibers begin to accumulate protein filaments important in muscle contraction. Muscle fibers aggregate into bundles as the fetus grows, and by birth myoblast activity, so the formation of new muscle fibers stops. Muscle fibers contain longitudinally arranged myofilaments, named actin and myosin. Muscle contraction on a subcellular level is a complex interaction of myofilaments coupled with the influx and efflux of calcium ions following the excitation by nerve fibers. Each muscle fiber is bound to adjacent fibers to form bundles and accumulation of muscle bundles forms the muscle belly. Supporting connective tissue surrounding the individual fibers is named endomysium, the perimysium encloses the fascicles, and the epimysium surrounds the muscle belly [3].

Nerve fibers innervating the muscles originate from brain stem nuclei or the spinal cord and meet the muscle fibers in neuromuscular junctions. Neuromuscular junctions are composed of presynaptic nerve membrane, synaptic cleft, and postsynaptic muscle membrane. Myelinated motor nerve fibers enter their target muscles and they divide into 20-100 unmyelinated terminal fibers, each of which innervates a single muscle fiber. The terminal fiber from a motor axon and the muscle fiber it innervates are called a motor unit. The terminal nerve fibers contain the neurotransmitter acetylcholine (ACh) stored in synaptic vesicles. When the nerve fibers are stimulated by an action potential, ACh is released into the synaptic cleft and binds to the $\mathrm{ACh}$ receptors on the postsynaptic muscle membrane initiating the muscle contraction [6].

\section{Stem Cells}

Stem cells can be classified according to the way that they are derived and the source tissues. Embryonic stem cells (ESCs), mesenchymal stem cells (MSCs), haemopoietic stem cells (HSCs), and induced pluripotent stem (iPS) cells are the major types of stem cells. Each one of these stem cell types possesses certain advantages and disadvantages which should be weighed carefully before the desired applications.

ESCs cells are derived from the inner cell mass of a developing blastocyst and are pluripotent, possessing the capacity to give rise to all 3 germ layers. Concerns about in vivo tumor formation and ethical concerns regarding their harvest have thus far restricted the use of ESCs [3]. MSCs and HSCs are multipotent, self-renewing cells derived from adult tissues that can form a number of cells or tissues that are usually restricted to a particular germ layer. The major advantages of the MSCs and HSCs over ES cells are the ease of harvest and lack of immunoreactivity since they are derived from autologous sources. However, they may be less desirable for the treatment of genetic diseases since they may possess the same genetic predisposition to the disease. For example, MSCs derived from ALS patients exhibit diminished growth and differentiation capacity [7].

Most recent advancement in the field of stem cell research is the development of iPS cells [8]. iPS cells are reprogrammed fibroblasts that are transfected by selected transcription factors delivered by vector-, virus-, protein-, or RNA-mediated approaches. Original protocol utilized transcription factors Oct 3/4, Klf, Sox2, and c-Myc; however multiple research groups have now accomplished successful reprogramming of fibroblasts using various combinations of factors [9-12]. These cells are not only an option for disease modeling but also provide a novel source for autologous cellular therapies [7].

Stem cells are used in two different ways in neurodegenerative diseases: direct differentiation and regeneration or paracrine anti-inflammatory activity. Moreover, stem cells might become eventually carriers of pharmacological and gene treatments [2].

\section{Amyotrophic Lateral Sclerosis}

ALS is a neurodegenerative disease caused by the selective loss of both spinal and upper motor neurons [13]. It is the most common motor neuron disease in adults and usually diagnosed in the sixth decade of life. Initial presentation is limb weakness which progresses gradually to generalized muscle atrophy and paralysis. Respiratory muscle involvement leads to death usually within 5 years. The definitive treatment of the disease is the replacement of the lost motor neurons. Many pharmacologic agents have been tried for the treatment of ALS but none of them proved to be effective up to date.

Stem cells have been extensively experimented for the treatment of ALS in animal models and some provided significant benefit in preclinical level (Table 1). The types of stem cells that have been tested include neural stem and progenitor cells (NSCs, NPC), umbilical cord blood stem cells (UCBCs), bone marrow stem cells (BMCs), human glial restricted progenitors (hGRPs), embryonal stem (ES) cells, glial restricted progenitors (GRPs), and olfactory bulb neural progenitor cells (OB-NPCs). There are around ten clinical trials reported so far placing the amyotrophic lateral sclerosis to the top of the list of clinical trials for neurodegenerative disorders (Table 2). Even though some of these trials reported a limited success in terms of prolonged life span and functional improvement, the desired level of success has not been reached yet. Mazzini et al. reported the first clinical application of BMCs to the patients with ALS but mainly focused on the safety of the procedure in this preliminary 
TABLE 1: Table summarizing the preclinical studies on the treatment of ALS with stem cells.

\begin{tabular}{|c|c|c|c|}
\hline Stem cell & Animal model & Result & References \\
\hline Mouse BMCs & SOD1 ${ }^{\mathrm{G} 93 \mathrm{~A}}$ mouse & No effect & {$[48]$} \\
\hline Mouse BMCs & $\mathrm{SOD} 1^{\mathrm{G} 93 \mathrm{~A}}$ mouse & Prolonged life span and functional improvement & [49] \\
\hline Mouse BMCs & $\mathrm{SOD} 1^{\mathrm{G} 93 \mathrm{~A}}$ mouse & Prolonged life span and delayed disease onset & {$[50]$} \\
\hline Mouse BMCs & SOD1 ${ }^{\mathrm{G} 93 \mathrm{~A}}$ mouse & Functional improvement & {$[51]$} \\
\hline Rat BMCs & SOD1 ${ }^{\text {Leu126delTT }}$ mouse & Prolonged life span in female mice only & {$[52]$} \\
\hline Rat BMCs & hSOD1(G93A) rat & $\begin{array}{l}\text { Prolonged life span, decreased motor neuron loss, } \\
\text { and preserved motor functions }\end{array}$ & {$[53]$} \\
\hline Rat BMCs & $\mathrm{SOD} 1^{\mathrm{G} 93 \mathrm{~A}}$ rat & Prolonged life span and functional improvement & {$[54]$} \\
\hline Human BMCs & SOD $1^{\mathrm{G} 93 \mathrm{~A}}$ mouse & Prolonged life span and delayed disease onset & {$[55]$} \\
\hline Human BMCs & SOD $1^{\mathrm{G} 93 \mathrm{~A}}$ mouse & $\begin{array}{l}\text { Prolonged life span functional improvement, and } \\
\text { delayed disease onset }\end{array}$ & {$[56]$} \\
\hline $\begin{array}{l}\text { Human BMCs or } \\
\text { Human BMC-derived NSCs }\end{array}$ & $\mathrm{SOD} 1^{\mathrm{G} 93 \mathrm{~A}}$ mouse & No effect & {$[57]$} \\
\hline Human BMCs & SOD1 ${ }^{\mathrm{G} 93 \mathrm{~A}}$ mouse & Functional improvement & {$[58]$} \\
\hline Human BMCs & SOD1 ${ }^{\mathrm{G} 93 \mathrm{~A}}$ rat & Prolonged life span and functional improvement & [59] \\
\hline Human UCBCs & SOD $1^{\mathrm{G} 93 \mathrm{~A}}$ mouse & Prolonged life span & {$[60]$} \\
\hline Human UCBCs & SOD1 ${ }^{\mathrm{G} 93 \mathrm{~A}}$ mouse & Prolonged life span & {$[61]$} \\
\hline Human UCBCs & SOD $1^{\mathrm{G} 93 \mathrm{~A}}$ mouse & Prolonged life span and functional improvement & {$[62]$} \\
\hline Human UCBCs & SOD1 ${ }^{\mathrm{G} 93 \mathrm{~A}}$ mouse & $\begin{array}{l}\text { Prolonged life span, functional improvement, } \\
\text { delayed disease onset, and histological } \\
\text { improvement }\end{array}$ & {$[63]$} \\
\hline Human UCBCs & SOD $1^{\mathrm{G} 93 \mathrm{~A}}$ mouse & No effect & {$[64]$} \\
\hline $\begin{array}{l}\text { Human UCBCs or } \\
\text { Human UCBC-derived NSCs }\end{array}$ & SOD $1^{\mathrm{G} 93 \mathrm{~A}}$ mouse & No effect & {$[57]$} \\
\hline Human UCBCs & SOD1 ${ }^{\mathrm{G} 93 \mathrm{~A}}$ mouse & $\begin{array}{l}\text { Prolonged life span and amelioration of the } \\
\text { symptoms }\end{array}$ & {$[65]$} \\
\hline Human UCBCs & SOD ${ }^{\mathrm{G} 93 \mathrm{~A}}$ mouse & Not mentioned & {$[66]$} \\
\hline Human NPC & $\mathrm{SOD} 1^{\mathrm{G} 93 \mathrm{~A}}$ rat & No effect & {$[67]$} \\
\hline Human NPC & SOD1 ${ }^{\mathrm{G} 93 \mathrm{~A}}$ rat & No effect & {$[68]$} \\
\hline Human NSCs & $\mathrm{SOD} 1^{\mathrm{G} 93 \mathrm{~A}}$ rat & $\begin{array}{l}\text { Prolonged life span, functional improvement, and } \\
\text { delayed disease onset }\end{array}$ & {$[69]$} \\
\hline Human NSCs & $\mathrm{SOD} 1^{\mathrm{G} 93 \mathrm{~A}}$ rat & Prolonged life span and functional improvement & {$[70]$} \\
\hline Human NSCs & SOD1 ${ }^{\mathrm{G} 93 \mathrm{~A}}$ mouse & Prolonged life span and delayed disease onset & {$[71]$} \\
\hline Human NSCs & $\mathrm{SOD} 1^{\mathrm{G} 93 \mathrm{~A}}$ rat & Prolonged life span & {$[69]$} \\
\hline Human NSCs & SOD $1^{\mathrm{G} 93 \mathrm{~A}}$ mouse & Improved neuromuscular transmission & {$[72]$} \\
\hline Mouse NSCs & SOD $1^{\mathrm{G} 93 \mathrm{~A}}$ mouse & Prolonged life span and delayed disease onset & {$[73]$} \\
\hline Rat NSCs & $\mathrm{SOD} 1^{\mathrm{G} 93 \mathrm{~A}}$ rat & Not mentioned & {$[74]$} \\
\hline Mouse OB-NPCs & SOD1 ${ }^{\mathrm{G} 93 \mathrm{~A}}$ mouse & $\begin{array}{l}\text { Prolonged life span, functional improvement, and } \\
\text { delayed disease onset }\end{array}$ & {$[75]$} \\
\hline Mouse ESCs & $\mathrm{SOD} 1^{\mathrm{G} 93 \mathrm{~A}}$ rat & No effect & {$[76]$} \\
\hline Human GRPs & SOD1 ${ }^{\mathrm{G} 93 \mathrm{~A}}$ mouse & Not mentioned & [77] \\
\hline
\end{tabular}

study [14]. They later on published larger patient series along with the long-term follow-up results $[2,15,16]$, and in their final paper in 2012 they stated that BMC application does not improve the symptoms of ALS in the long term, however, stabilizes the symptoms of the disease thus prolonging the life span of the patients [17]. On the other hand, Nefussy et al. could not detect any benefit of stem cell treatment in case of ALS, but it should be mentioned that they mobilized the BMCs via injection of granulocyte colony stimulating factor (G-CSF) but did not carry out direct injection of the cells [18]. A common finding of these clinical trials was the lack of major side effects of intraspinal/intracerebral cell injection that makes the clinicians more comfortable in continuing their efforts for the refinement of the stem cell therapies for ALS [14, 15, 19, 20]. Therefore, more clinical trials are on the way and there are nine more in various stages listed in the NIH database for clinical trials. 
TABLE 2: Table summarizing the clinical trials on the treatment of ALS with stem cells.

\begin{tabular}{|c|c|c|c|c|}
\hline Phase & Stem cell & Followup & Results & Reference \\
\hline- & BMCs & & $\begin{array}{l}\text { No adverse effects observed but } \\
\text { final result not mentioned }\end{array}$ & {$[14]$} \\
\hline- & BMCs & 3 years & $\begin{array}{l}\text { A significant slowing down of the } \\
\text { linear decline of the forced vital } \\
\text { capacity }\end{array}$ & {$[2]$} \\
\hline- & BMCs & 4 years & $\begin{array}{l}\text { No adverse effects observed but } \\
\text { final result not mentioned }\end{array}$ & {$[15]$} \\
\hline- & $\begin{array}{c}\text { G-CSF } \\
\text { mobilized HSCs }\end{array}$ & 6 months & $\begin{array}{l}\text { No adverse effects observed but } \\
\text { final result not mentioned }\end{array}$ & {$[19]$} \\
\hline II & $\begin{array}{l}\text { BM derived } \\
\text { HSCs }\end{array}$ & 1 year & $\begin{array}{l}9 \text { patients showed clinical } \\
\text { improvement confirmed by } \\
\text { electroneuromyography. One } \\
\text { patient was stabilized. No benefit } \\
\text { observed in three patients }\end{array}$ & {$[78]$} \\
\hline- & $\begin{array}{c}\text { G-CSF } \\
\text { mobilized HSCs }\end{array}$ & 1 year & $\begin{array}{l}\text { No adverse effects observed. } \\
\text { Increased survival }\end{array}$ & {$[79]$} \\
\hline $\mathrm{I} / \mathrm{II}$ & BMCs & 6 months & $\begin{array}{l}\text { No adverse effects observed, disease } \\
\text { symptoms stabilized }\end{array}$ & {$[80]$} \\
\hline I-II & BMCs & 6 months & $\begin{array}{l}\text { Minor side effects were transient } \\
\text { fever, headache. No major adverse } \\
\text { effects were observed. Clinical } \\
\text { improvement observed }\end{array}$ & {$[81]$} \\
\hline - & $\begin{array}{c}\text { G-CSF } \\
\text { mobilized HSCs }\end{array}$ & - & No clinical benefit & {$[18]$} \\
\hline - & $\begin{array}{c}\text { G-CSF } \\
\text { mobilized HSCs }\end{array}$ & - & $\begin{array}{l}\text { No adverse effects but final result } \\
\text { not mentioned }\end{array}$ & {$[20]$} \\
\hline I & BMCs & 1 year & $\begin{array}{l}\text { No adverse effects observed but } \\
\text { final result not mentioned }\end{array}$ & {$[16]$} \\
\hline I & BMCs & 9 years & $\begin{array}{l}\text { No clinical benefit in long-term } \\
\text { followup but the symptoms } \\
\text { stabilized }\end{array}$ & {$[17]$} \\
\hline
\end{tabular}

\section{Multiple Sclerosis}

MS is a chronic inflammatory demyelinating disease of the central nervous system that leads to cumulative and irreversible damage. MS is characterized by self-reactive lymphocytes and demyelination. Therefore, any method for the treatment of MS, to be effective, should reverse the demyelination as well as suppressing self-reacting lymphocytes. Available drug therapies are only partially effective in these terms. However, stem cells, considering their immunosuppressive effects and multilineage differentiation capacity, may be applicable for meeting some of these goals. Preclinical data and ongoing clinical trials suggest that selected patients may respond positively to autologous stem cell transplantation. But it is still uncertain if adult stem cells can repair existing neurological deficits in patients with MS [21].

The stem cell types that have been used for the treatment of MS in animal models were BMCs, iPS, NSCs, NPCs, HSCs, ESCs, adipose-derived stem cells (ASCs), embryonal carcinoma cells, bone marrow transplantation (BMT), Schwann cells (SCs), Schwann cell precursors (SCPs), and oligodendrocyte progenitor (OCP) cells. It was Bonilla et al. who first used stem cells for the treatment of MS [22].
They have injected BM-derived HSCs into the mouse brain and obtained encouraging results. Numerous studies have followed and they are listed in Table 3. Oka et al. used primates for their experiments and injected monkey NPCs into the central nervous system of the monkeys to treat MS [4] (Figure 1). They have seen significant number of myelinating fibers in the transplantation zone. In another primate study it was reported that transplanted human NPCs decreased disability and increased survival of the animals [23]. The results of these two experiments were important in terms of the proximity of the animal model to human beings. The potential of iPS cells to differentiate into functional OPCs, as documented recently, is another milestone development that would ameliorate the stem cell donor site issues [24]. There is only one controversial study in the literature published by Reekmans et al. in which mouse NSCs were transplanted to a mouse MS model but no therapeutic effect or improvement in the disease state could be detected [25].

Clinical trials on the treatment of MS with stem cells are listed in Table 4. In the standard protocol, patients are first treated with a combination of immunosuppressive agents to eliminate all lymphocytes including self-reactive lymphocytes. Myeloablative treatment is followed by stem 
TABLE 3: Table summarizing the preclinical studies on the treatment of MS with stem cells.

\begin{tabular}{|c|c|c|c|}
\hline Stem cell & Animal model & Result & References \\
\hline Mouse BM-derived HSCs & Neonatal mouse & $\begin{array}{l}\text { Injected stem cells differentiated into } \\
\text { oligodendroglial cells in vivo }\end{array}$ & {$[22]$} \\
\hline Rat NPCs & Rat & $\begin{array}{l}\text { Transplanted cells had migrated into white } \\
\text { matter and acquired specific markers of the } \\
\text { astroglial and oligodendroglial lineages }\end{array}$ & {$[82]$} \\
\hline Mouse NPCs & Mouse & $\begin{array}{l}\text { Significant numbers of donor cells entered } \\
\text { into demyelinating areas of the central } \\
\text { nervous system and differentiated into } \\
\text { mature brain cells }\end{array}$ & {$[83]$} \\
\hline Mouse NPCs & Mouse & $\begin{array}{l}\text { The size of demyelinated areas and, extent of } \\
\text { chronic axonal pathology were reduced in } \\
\text { the transplanted brains }\end{array}$ & {$[84]$} \\
\hline Mouse NPCs & Mouse & $\begin{array}{l}\text { Decreased CNS inflammation and tissue } \\
\text { injury and attenuated severity of EAE }\end{array}$ & {$[85]$} \\
\hline Mouse NPCs & Mouse & $\begin{array}{l}\text { Transplanted NPCs accumulated in } \\
\text { inflammatory demyelinating lesions }\end{array}$ & {$[86]$} \\
\hline Mouse NPCs & Mouse & $\begin{array}{l}\text { Decreased inflammation in brain but no } \\
\text { effect in spinal cord lesions }\end{array}$ & [87] \\
\hline Mouse NPCs & Mouse & $\begin{array}{l}\text { Reduced migration of transplanted cells in } \\
\text { chronic disease }\end{array}$ & {$[88]$} \\
\hline Mouse NPCs & Mouse & Enhanced remyelination & {$[84]$} \\
\hline Mouse NPCs & Mouse & $\begin{array}{l}\text { NPC differentiated into oligodendrocytes in } \\
\text { vivo in long term }\end{array}$ & {$[87]$} \\
\hline $\begin{array}{l}\text { Mouse NPCs committed to glial } \\
\text { lineage }\end{array}$ & Mouse & $\begin{array}{l}\text { Migration of cells from the implantation site } \\
\text { and remyelination of axons. Behavioral } \\
\text { improvement }\end{array}$ & [89] \\
\hline $\begin{array}{l}\text { Mouse NPCs committed to glial } \\
\text { lineage }\end{array}$ & Mouse & $\begin{array}{l}\text { Remyelination of the axons was observed } \\
\text { without alteration of T cells or macrophages } \\
\text { within the CNS }\end{array}$ & {$[90]$} \\
\hline Human NPCs & Monkey & $\begin{array}{l}\text { Decreased disability and increased survival } \\
\text { as well as long-term survival of implanted } \\
\text { cells }\end{array}$ & {$[23]$} \\
\hline Human ESC-derived NPCs & Mouse & $\begin{array}{l}\text { Clinical improvement, cells migrated to the } \\
\text { host white matter, attenuation of the } \\
\text { inflammatory process }\end{array}$ & [91] \\
\hline Monkey NPCs & Monkey & $\begin{array}{l}\text { Significant number of myelinating profiles } \\
\text { in the transplantation zone }\end{array}$ & {$[4]$} \\
\hline BM transplantation & Mouse & $\begin{array}{l}\text { Complete amelioration of the symptoms of } \\
\text { MS }\end{array}$ & {$[92]$} \\
\hline $\mathrm{BM}$ transplantation & Mouse & $\begin{array}{l}\text { BM transplantation effectively blocked or } \\
\text { delayed EAE development }\end{array}$ & [93] \\
\hline BM transplantation & Mouse & Protection from disease development & {$[94]$} \\
\hline $\begin{array}{l}\text { NT2 embryonal carcinoma cell } \\
\text { line, } \\
\text { BM transplantation }\end{array}$ & Mouse & $\begin{array}{l}\text { Both types of cells remained viable in the } \\
\text { mouse brain and differentiated into neurons, } \\
\text { astrocytes, and oligodendrocytes }\end{array}$ & [95] \\
\hline Mouse NSCs & Mouse & $\begin{array}{l}\text { NSCs migrated and differentiated into } \\
\text { oligodendrocytes and stimulated } \\
\text { remyelination }\end{array}$ & {$[96]$} \\
\hline $\begin{array}{l}\text { Mouse NSCs and mouse } \\
\text { BMC-derived NSCs }\end{array}$ & Mouse & $\begin{array}{l}\text { Both cell types suppressed the inflammatory } \\
\text { process }\end{array}$ & [97] \\
\hline Human BMCs & Mouse & $\begin{array}{l}\text { Demyelination and the number of the } \\
\text { lesions have decreased }\end{array}$ & {$[98]$} \\
\hline
\end{tabular}


TABle 3: Continued.

\begin{tabular}{|c|c|c|c|}
\hline Stem cell & Animal model & Result & References \\
\hline Mouse NSCs & Mouse & Limited or no therapeutic potential & [25] \\
\hline Mouse BMCs & Mouse & $\begin{array}{l}\text { Antioxidant and neuroprotective activity for } \\
\text { MSCs was documented }\end{array}$ & [99] \\
\hline Mouse BMCs & Mouse & $\begin{array}{l}\text { Decreased inflammation and decreased } \\
\text { tissue levels of inflammatory mediators }\end{array}$ & {$[100]$} \\
\hline Mouse BMCs & Mouse & $\begin{array}{l}\text { BMCs enhanced recovery, prevented } \\
\text { relapses, and promoted myelin repair }\end{array}$ & {$[101]$} \\
\hline Mouse BMCs & Mouse & $\begin{array}{l}\text { Transplanted cells decreased the } \\
\text { inflammation but also formed } \\
\text { demyelinating lesions in the brain } \\
\text { parenchyma in some cases }\end{array}$ & {$[102]$} \\
\hline Human BMCs & Mouse & $\begin{array}{l}\text { Injected BMCs accumulated in the CNS, } \\
\text { reduced the extent of damage, and increased } \\
\text { oligodendrocyte lineage cells in lesion areas }\end{array}$ & [103] \\
\hline $\begin{array}{l}\text { Human BMCs differentiated into } \\
\text { neurotrophic factor-producing } \\
\text { cells }\end{array}$ & Mouse & $\begin{array}{l}\text { Delay of symptom onset and increased } \\
\text { animal survival }\end{array}$ & [104] \\
\hline $\begin{array}{l}\text { TREM2* -transduced } \\
\text { BM-derived myeloid precursor } \\
\text { cells }\end{array}$ & Mouse & $\begin{array}{l}\text { Limited tissue destruction and facilitated } \\
\text { repair }\end{array}$ & [105] \\
\hline $\begin{array}{l}\text { IFN- } \beta^{* *} \text { gene transfected mouse } \\
\text { BMCs }\end{array}$ & Mouse & $\begin{array}{l}\text { Inhibition of disease onset and decrease in } \\
\text { clinical severity. }\end{array}$ & [106] \\
\hline $\begin{array}{l}\text { BDNF }^{* * *} \text { gene transfected } \\
\text { mouse BMCs }\end{array}$ & Mouse & $\begin{array}{l}\text { Delayed disease onset and a reduction in } \\
\text { overall clinical severity }\end{array}$ & {$[107]$} \\
\hline Mouse ASCs & Mouse & $\begin{array}{l}\text { Bimodal therapeutic potential of ASCs was } \\
\text { documented via suppressing the } \\
\text { autoimmune response and via inducing } \\
\text { local neuroregeneration }\end{array}$ & [108] \\
\hline SC and SCPs & Rat & $\begin{array}{l}\text { SCPs survived well, migrate through normal } \\
\text { CNS tissue, interface smoothly and } \\
\text { intimately with host glial cells, and } \\
\text { myelinate extensively among the astrocytes } \\
\text { of the retina }\end{array}$ & [109] \\
\hline Mouse OPCs and BMCs & Mouse & $\begin{array}{l}\text { BMCs increased OPC engraftment, } \\
\text { migration, and maturation in myelinating } \\
\text { oligodendrocytes }\end{array}$ & [110] \\
\hline Mouse iPS derived OPC & Mouse & $\begin{array}{l}\text { iPS cells could be differentiated into } \\
\text { functional OPCs }\end{array}$ & {$[24]$} \\
\hline OPC line CG-4 & Rat & $\begin{array}{l}\text { Transplanted cells migrated to inflammatory } \\
\text { lesions and differentiated into } \\
\text { oligodendrocytes }\end{array}$ & [111] \\
\hline
\end{tabular}

cell transplantation. However, direct intrathecal injection of stem cells as well as nonmyeloablative stem cell transplantation has also been tried with favorable results [26, 27]. The largest series published so far includes 183 patients that are recorded in the database of the European Blood and Marrow Transplantation Group [28]. All these patients were treated with HSCs, and overall transplant-related mortality was $5.3 \%$ with an improvement or stabilization of neurological conditions in $63 \%$ of patients during a median followup of 41.7 months. The only reported serious side effect of stem cell treatment of MS was the Epstein-Barr virus-associated posttransplantation lymphoproliferative disorder [29]. In summary, both myeloablative or nonmyeloablative stem cell applications seem to be safe and both provide a certain level of clinical benefit to the patients.

\section{Muscular Dystrophies}

DMD is characterized by a progressive degeneration of the whole body musculature due to a deficit in the dystrophin gene. Dystrophin is a large protein of skeletal muscle tissue that is expressed under the sarcolemma and contributes to the stability of the giant syncytial muscle fibers. Natural course 


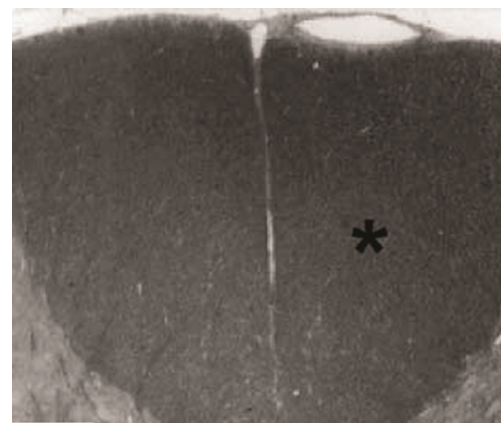

(a)
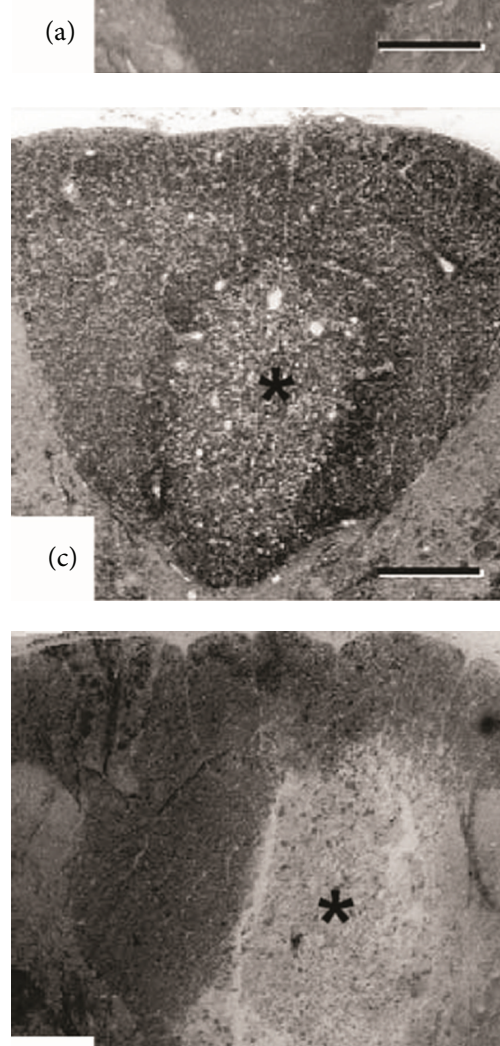

(e)

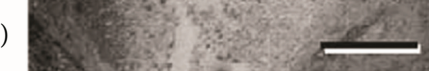

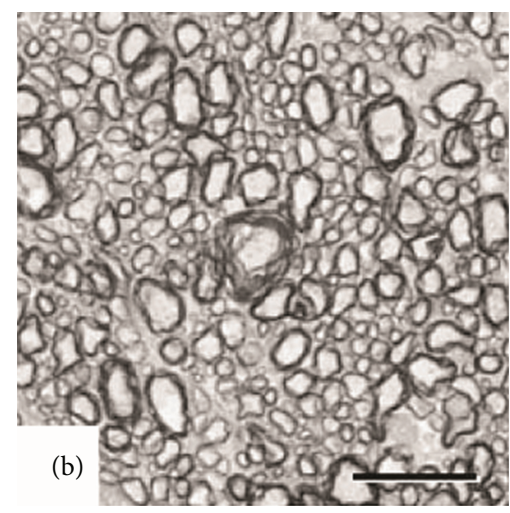
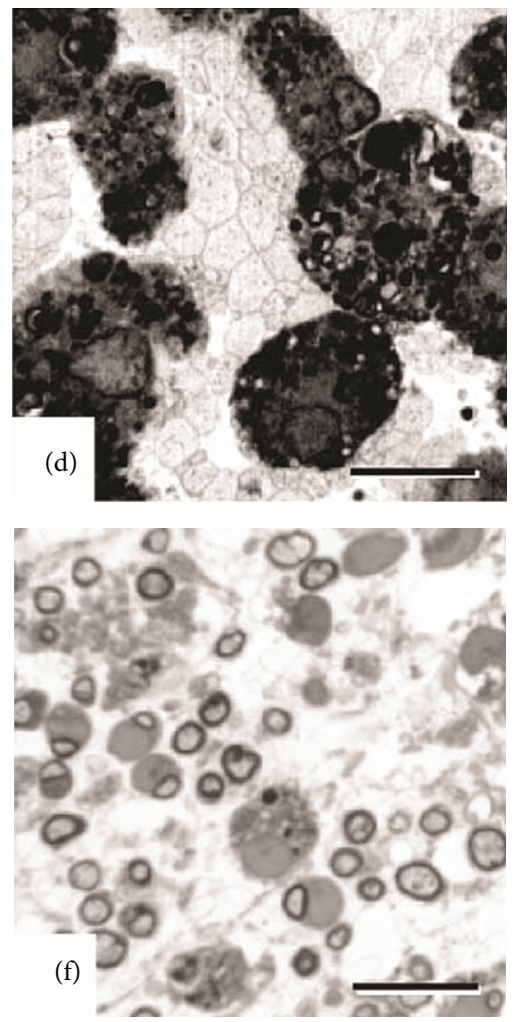

FIGURE 1: Remyelination of the marmoset spinal cord following transplantation of adult marmoset precursor cells. Normal (a), demyelinated (c), and remyelinated (e) axons of the dorsal column in the marmoset. (b), (d), and (f) are highpower magnification of the area around the asterisk in (a), (c), and (e), respectively. The anatomical pattern of myelination was similar to that produced by the Schwann cells (scale bar, for $(\mathrm{a}),(\mathrm{c})$, and $(\mathrm{e})=250 \mathrm{Am}$, for $(\mathrm{b}),(\mathrm{d})$, and $(\mathrm{f})=10 \mathrm{Am})$. Adapted from [4].

of the disease is confinement to wheelchairs around the age of 12 and death ensues in the later stages due to cardiomyopathy. During the course of the disease, effected skeletal muscle tissue regenerates to a limited extend through the activation of satellite cells but multiple cycles of degenerationregeneration eventually lead to exhaustion of the myogenic reservoir. Replenishment of the myogenic reservoir is the principle of the stem cell transplantation to the skeletal muscle in muscular dystrophies. BMD is very similar to DMD except that it gets worse at a much slower rate and it is less common [30].

DMD and BMD are the most extensively studied diseases in the group of neuromuscular disorders. Therefore it would be overwhelming to cite all the experimental papers on treatment of muscular dystrophies in this paper. Instead, a general summary of the preclinical studies is given in Table 5 . The most commonly used cell type in preclinical studies was myoblasts that originate from myogenic progenitors (MPCs), and the main MPCs in skeletal muscles are satellite cells. These normally quiescent cells are located beneath the muscle fiber basal lamina, and upon activation they either differentiate into committed progenitors (myoblasts) or self-renew by asymmetric division [3, 30, 31]. However, the first experimental report by Ferrari et al. utilized BMderived MPCs in a mouse model of muscle degeneration [32]. Lafreniere et al. carried out the only primate study 
TABLE 4: Table summarizing the clinical trials on the treatment of MS with stem cells.

\begin{tabular}{|c|c|c|c|c|}
\hline Phase & Stem cell & Followup & Results & Reference \\
\hline $\mathrm{I} / \mathrm{II}$ & HSCs & 15 months & $\begin{array}{l}\text { The number of lesions decreased on MRI. } \\
\text { Clinically, patients improved slightly or remained } \\
\text { stable }\end{array}$ & [112] \\
\hline- & HSCs & $1-1.5$ years & $\begin{array}{l}\text { A fall in intensity of motor and coordination } \\
\text { disorders. No recovery of cranial nerve function } \\
\text { was observed }\end{array}$ & {$[113]$} \\
\hline $\mathrm{I} / \mathrm{II}$ & HSCs & 16 months & Positive early results & {$[114]$} \\
\hline II & HSCs & 12 months & $\begin{array}{l}\text { EDSS improved in some patients. Only two } \\
\text { patients had relapses Disappearance of enhanced } \\
\text { T1 lesions on MRI }\end{array}$ & [115] \\
\hline II & HSCs & 24 months & $\begin{array}{l}\text { Important clinical issues in the use of HDIT and } \\
\text { stem cell transplantation for MS were identified }\end{array}$ & {$[116]$} \\
\hline II & HSCs & 36 months & $\begin{array}{l}\text { All patients showed clinical stabilization or } \\
\text { improvement. Quality of life improved }\end{array}$ & [117] \\
\hline- & HSCs & 2 years & $\begin{array}{l}\text { Long-term suppression of inflammatory activity } \\
\text { in MS patients who received HSCs is associated } \\
\text { with profound qualitative immunological changes }\end{array}$ & {$[118]$} \\
\hline- & HSCs & 3 years & $\begin{array}{l}\text { HSCs can reduce BDNF levels to values associated } \\
\text { with lower activity }\end{array}$ & [119] \\
\hline- & HSCs & 41.7 months & $\begin{array}{l}\text { Improvement or stabilization of neurological } \\
\text { conditions in } 63 \% \text { of patients. HSCs was shown as } \\
\text { a promising procedure to slow down progression } \\
\text { in a subset of patients affected by severe, } \\
\text { progressive MS }\end{array}$ & {$[28]$} \\
\hline- & BMCs & 19 months & $\begin{array}{l}\text { Some degree of improvement in the sensory, } \\
\text { pyramidal, and cerebellar functions noted }\end{array}$ & {$[120]$} \\
\hline $\mathrm{I} / \mathrm{II}$ & HSCs & 37 months & $\begin{array}{l}\text { All patients were free from progression (no } \\
\text { deterioration in EDSS), and } 16 \text { were free of } \\
\text { relapses. Significant improvements were noted in } \\
\text { neurological disability }\end{array}$ & {$[27]$} \\
\hline I & BMCs & 12 months & $\begin{array}{l}\text { EDSS improvement in } 5 / 7 \text {, stabilization in } 1 / 7 \text {, } \\
\text { and worsening in } 1 / 7 \text { patients. Hints of clinical } \\
\text { but not radiological efficacy and evidence of safety } \\
\text { with no serious adverse events }\end{array}$ & {$[26]$} \\
\hline- & HSCs & 48.92 months & $\begin{array}{l}\text { Confirmed relapse-free survival rate was } 62.9 \% \\
\text { and progression-free survival rate was } 83.3 \%\end{array}$ & {$[121]$} \\
\hline $\mathrm{I} / \mathrm{II}$ & BMCs & $\leq 25$ months & $\begin{array}{l}\text { Transplantation of MSCs in patients with MS and } \\
\text { ALS is a clinically feasible and relatively safe } \\
\text { procedure and induces immediate } \\
\text { immunomodulatory effects }\end{array}$ & {$[81]$} \\
\hline- & BMCs & - & $\begin{array}{l}\text { Expression of FoxP3 at } 6 \text { months after intrathecal } \\
\text { injection of MSC was significantly higher than the } \\
\text { levels prior to treatment. Such significant } \\
\text { enhanced expression of FoxP3 associated with } \\
\text { clinical stability }\end{array}$ & {$[122]$} \\
\hline- & BMCs & 12 months & $\begin{array}{l}\text { Improvement of EDSS by } 0.5-1 \text { points in } 6 / 8 \text {, } \\
\text { stabilization in } 1 / 8 \text {, and progression in } 1 / 8 \\
\text { patients }\end{array}$ & {$[123]$} \\
\hline IIa & BMCs & 10 months & $\begin{array}{l}\text { There were no safety issues of stem cell } \\
\text { application. The evidence of structural, } \\
\text { functional, and physiological improvement after } \\
\text { treatment in some visual endpoints is suggestive } \\
\text { of neuroprotection }\end{array}$ & {$[124]$} \\
\hline
\end{tabular}


TABLE 5: Table summarizing the preclinical studies on the treatment of muscular dystrophies with stem cells.

\begin{tabular}{|c|c|}
\hline Stem cell & References \\
\hline $\begin{array}{l}\text { Mouse BMCs (as a vehicle for gene } \\
\text { delivery) }\end{array}$ & {$[34,35]$} \\
\hline Mouse BMCs & $\begin{array}{c}{[39,125-} \\
128]\end{array}$ \\
\hline Mouse HSCs & {$[40]$} \\
\hline Dog HSCs & [129] \\
\hline Human HSCs & {$[130]$} \\
\hline Human BMCs & {$[131,132]$} \\
\hline $\begin{array}{l}\text { Mouse MDSCs (as a vehicle for gene } \\
\text { delivery) }\end{array}$ & {$[36]$} \\
\hline Mouse MDSCs & {$[133-135]$} \\
\hline Dog MDSCs & [136] \\
\hline Human MDSCs & {$[137,138]$} \\
\hline $\begin{array}{l}\text { Mouse mesoangioblasts (as a vehicle for } \\
\text { gene delivery) }\end{array}$ & {$[5]$} \\
\hline Mouse mesoangioblasts & {$[139-142]$} \\
\hline Canine mesoangioblasts & [143] \\
\hline Mouse iPS & {$[144-146]$} \\
\hline Human ASCs & {$[147-152]$} \\
\hline Mouse myoblasts/MPCs & $\begin{array}{c}{[135,153-} \\
165]\end{array}$ \\
\hline Dog myoblast/MPCs & {$[166]$} \\
\hline Porcine myoblast/MPCs & {$[167]$} \\
\hline Monkey myoblasts/MPCs & {$[33]$} \\
\hline Human myoblast/MPCs & {$[168-172]$} \\
\hline Human UCBCs & $\begin{array}{c}{[148,173,} \\
174]\end{array}$ \\
\hline Human SSCs ${ }^{*}$ & {$[175,176]$} \\
\hline Mouse ESCs & {$[177,178]$} \\
\hline Mouse ESC-derived myogenic precursors & [179] \\
\hline $\begin{array}{l}\text { Mouse BMC-derived myogenic } \\
\text { precursors }\end{array}$ & {$[32,180]$} \\
\hline Mouse satellite cells & {$[38]$} \\
\hline Human primordial germ cells & {$[181]$} \\
\hline Human IDPSC ${ }^{* *}$ & {$[182]$} \\
\hline Human primary fetal skeletal muscle cells & {$[183]$} \\
\hline $\mathrm{hfMSCs}^{* * *}$ & {$[184,185]$} \\
\hline BM transplantation (in mice) & {$[186]$} \\
\hline $\begin{array}{l}\text { Mouse side population cells (as a vehicle } \\
\text { for gene delivery) }\end{array}$ & {$[37]$} \\
\hline
\end{tabular}

and reported that the grafted cells fused only with the recipient fibers at the injection site but did not migrate for so long distances limiting the success of the treatment [33]. Gene delivery methods using stem cells as vehicles proved some improvement $[5,34-37]$. Tedesco et al. transplanted genetically corrected mesoangioblasts in SCID/mdx mice intramuscularly [5]. They have successfully documented the dystrophin production and amelioration of morphological defects in tibialis anterior muscle of SCID/mdx mice following cell transplantation (Figure 2). While most of the other studies documented the limited success of stem cell treatment in muscular dystrophies, some others reported no benefit [38-40].

Despite the high number of preclinical studies and encouraging data, clinical trials have been hampered by poor survival and limited migratory ability of the cells (Table 6). Neumeyer et al. reported no positive effect of myoblast transplantation into the tibialis anterior muscles of the patients with BMD [41]. Skuk et al. could detect fusion of the donor and recipient muscle fibers and subsequent synthesis of donor dystrophin following MPC allotransplantation; however this observation was limited to the injection sites [42]. Zhang et al. reported similar results following the transplantation of allogeneic human UCBCs [43]. Oxidative stress, fusion inability, and some administration methodologies are the suspected causes of poor cell survival following transplantation. Intramuscular administration was the preferred method of cellular delivery in most of the clinical studies since many cell types are not able to cross the endothelial barriers of the skeletal muscle tissue. The migration of the injected cells was generally restricted to short distances from the injection site. The resultant large intramuscular pockets of cells subsequently lead to cell death due to inefficient nutrient supply in vivo. Currently, there is only one ongoing clinical trial on stem cell treatment of muscular dystrophies in the NIH database. In this study the researchers aim to treat DMD by human UCBC transplantation.

\section{Myasthenia Gravis}

MG is an Ach receptor antibody-mediated autoimmune neuromuscular disease. The pathogenesis of MG involves the hyperactivity of $\mathrm{T}$ lymphocytes, activation of complement system, deficiency of immunomodulation, and impairment of immune homeostasis.

MSC has got the potential to correct impaired immune homeostasis in diseases like MG because they express intercellular adhesion molecule (ICAM)-1, ICAM-2, lymphocyte function-associated antigen (LFA) 3, fibronectin, lamin, and collagen, which are involved in the process of immune reaction. Moreover MSCs can modulate the T lymphocyte function via direct physical contact through the cell adhesion molecules $[44,45]$. However, there are a just a few experimental studies on the application of stem cells for the treatment of MG. The first study was published by Yu et al. [44]. In this study BMCs were applied intravenously to a mouse model of MG. The authors noted a significant decrease in the circulating levels of Ach receptor IgG antibody and a significant functional improvement. The same group injected human UCBCs to mouse model of MG in another experiment and obtained similar results [46]. Sheng et al. injected granulocyte macrophage colony stimulating factor (GM-CSF) to a mouse model of MG and noted a decreased immune response against the Ach receptors through the mobilization of tolerogenic precursor cells [47]. The results 

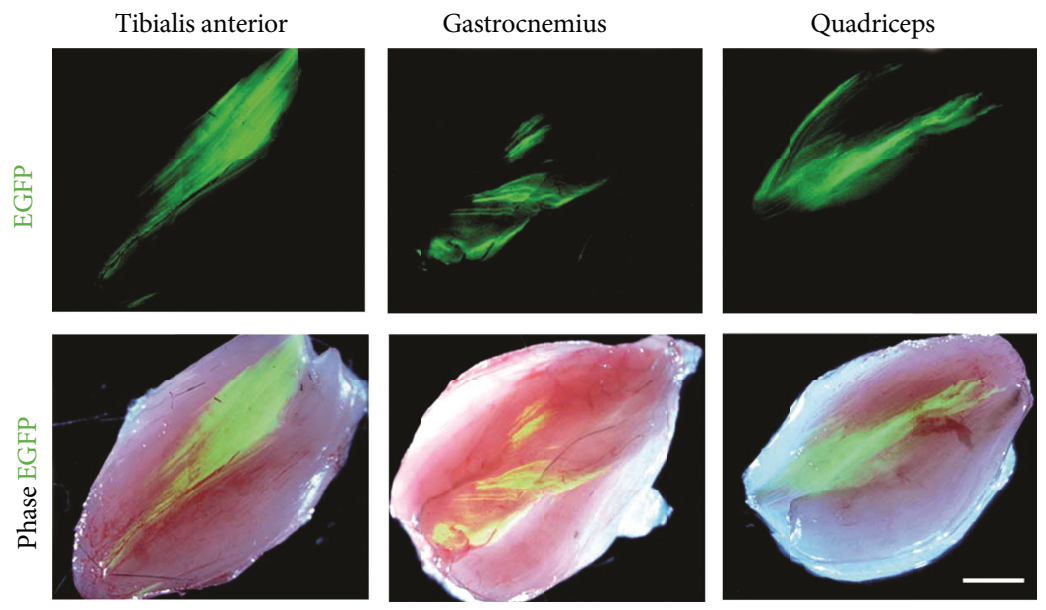

(a)
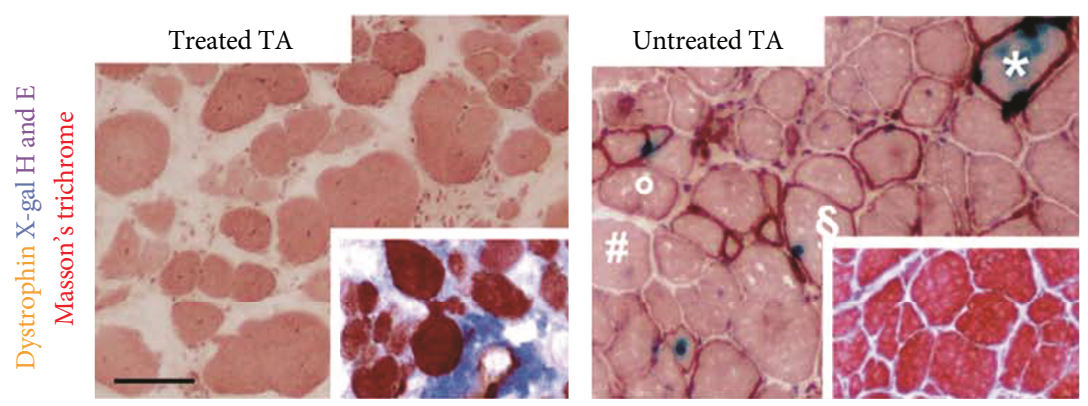

(b)

FIGURE 2: Intramuscular transplantation of genetically corrected mesoangioblasts in SCID/mdx mice. (a) Representative images showing the tibialis anterior (TA), gastrocnemius, and quadriceps muscles that received three intramuscular injections of $10^{6}$ corrected mesoangioblasts. Images show engraftment of donor cells demonstrated by EGFP fluorescence (green) 3 weeks after the last injection (scale bar, 2 mm). (b) Donor cell engraftment, dystrophin production, and amelioration of morphological defects in tibialis anterior muscle from a treated $\mathrm{SCID} / \mathrm{mdx}$ mouse compared with an untreated SCID/mdx mouse. Insets show Masson trichrome staining. *, $\$$,, and \# indicate strong, intermediate, weak, and no dystrophin positivity, respectively (scale bar, $100 \mathrm{~mm}$ ). Adapted from [5].

TABLE 6: Table summarizing the clinical trials on the treatment of muscular dystrophies with stem cells.

\begin{tabular}{|c|c|c|c|c|}
\hline Phase & Stem cell & Followup & Results & Reference \\
\hline- & Myoblast/MPCs & 1 year & No improvement in muscle strength. & {$[41]$} \\
\hline- & Myoblast/MPCs & 4 weeks & $\begin{array}{l}\text { Allotransplantation of normal MPCs induced the } \\
\text { expression of donor-derived dystrophin, however } \\
\text { this expression was restricted to the sites of } \\
\text { injection. }\end{array}$ & {$[42]$} \\
\hline \multirow[t]{2}{*}{ I } & MDSCs & 7 months & $\begin{array}{l}\text { No local or systemic side effects were observed. } \\
\text { Treated patients had an increased ratio of } \\
\text { capillary per muscle fibers with a switch from } \\
\text { slow to fast myosin-positive myofibers. }\end{array}$ & [187] \\
\hline & UCBCs & 100 days & $\begin{array}{l}\text { Restoration of the dystrophin in muscles, and } \\
\text { improvement of the locomotive function. }\end{array}$ & {$[43]$} \\
\hline
\end{tabular}

of these experiments were encouraging in terms of clinical application, and a phase I clinical trial is already on the way (ClinicalTrials.gov identifier: NCT00424489). The purpose of this study was stated as to assess the toxicity/feasibility of autologous hematopoietic stem cell transplantation for refractory MG cases in the NIH database. Several other studies are required to assess the feasibility of stem cell therapy for MG, and the concerns about the safety of the stem cell application in case of MG should be further investigated.

\section{Discussion and Conclusions}

Stem cells are the regenerative reservoirs of the body. They are located in niches in the tissues and become active in case of tissue injury to replace the degenerated cells. There 
are two possible mechanisms for the therapeutic effects of the stem cells: differentiation into different cell types or paracrine secretion. Some neuromuscular diseases like MS, ALS, and MG have got an inflammatory component, and in this case anti-inflammatory and immunomodulatory effects of stem cells could provide a treatment. In case of muscular dystrophies, the mechanism is the degeneration of muscle fibers rather than autoimmune destruction so the differentiation capacity of the stem cells comes forward.

Currently there is a gap between animal and human applications of stem cells in neuromuscular disorders so as the promising results obtained in animal studies have not been reproduced in clinical trials yet. The reasons for this failure can be summarized as limited differentiation of stem cells into required cell types, short survival times of transplanted cells, and lack of widespread effect due to the limited migration of the cells away from the injection site. In case of neuromuscular diseases, the preferred way for the delivery of the cells should be direct injection to the target tissues since the biological barriers may limit the migration of stem cells to the target tissues thus decreasing the efficacy of the treatment. Nevertheless lack of long distance migration of the stem cells in the tissues is still a major obstacle in front of cellular therapies as mentioned above. Ideas like corrective gene delivery via stem cells are theoretically brilliant, however, despite some improvement, they have not reached the desired clinical effectiveness yet. One single common result of stem cell trials is the safety of the procedure. Therefore further research can safely be carried out to overcome the current obstacles. Moreover, introduction of new stem cell types such as iPS cells will help to overcome donor site and ethical issues and increase the availability of stem cells.

In conclusion, stem cells still hold a great promise for the treatment of traditionally untreatable diseases. Continuing research will enable the clinicians to understand the biological processes of the neuromuscular diseases better and allow the modification of current treatment protocols accordingly. However the expectations from clinical applications should be kept realistic, and more importantly best effort should be done to prevent the worsening of the pathologies by cellular treatments.

\section{References}

[1] O. Paciello and S. Papparella, "Histochemical and immunohistological approach to comparative neuromuscular diseases," Folia Histochemica et Cytobiologica, vol. 47, no. 2, pp. 143-152, 2009.

[2] L. Mazzini, K. Mareschi, I. Ferrero et al., "Autologous mesenchymal stem cells: clinical applications in amyotrophic lateral sclerosis," Neurological Research, vol. 28, no. 5, pp. 523-526, 2006.

[3] S. MacLean, W. S. Khan, A. A. Malik, S. Anand, and M. Snow, "The potential of stem cells in the treatment of skeletal muscle injury and disease," Stem Cells International, vol. 2012, Article ID 282348, 9 pages, 2012.

[4] S. Oka, O. Honmou, Y. Akiyama et al., "Autologous transplantation of expanded neural precursor cells into the demyelinated monkey spinal cord," Brain Research, vol. 1030, no. 1, pp. 94-102, 2004.

[5] F. S. Tedesco et al., "Stem cell-mediated transfer of a human artificial chromosome ameliorates muscular dystrophy," Science Translational Medicine, vol. 3, no. 96, p. 96ra78, 2011.

[6] N. P. Hirsch, "Neuromuscular junction in health and disease," British Journal of Anaesthesia, vol. 99, no. 1, pp. 132-138, 2007.

[7] J. S. Lunn, S. A. Sakowski, J. Hur, and E. L. Feldman, "Stem cell technology for neurodegenerative diseases," Annals of Neurology, vol. 70, no. 3, pp. 353-361, 2011.

[8] K. Takahashi and S. Yamanaka, "Induction of pluripotent stem cells from mouse embryonic and adult fibroblast cultures by defined factors," Cell, vol. 126, no. 4, pp. 663-676, 2006.

[9] J. Hanley, G. Rastegarlari, and A. C. Nathwani, "An introduction to induced pluripotent stem cells," British Journal of Haematology, vol. 151, no. 1, pp. 16-24, 2010.

[10] H. J. Cho, C. S. Lee, Y. W. Kwon et al., "Induction of pluripotent stem cells from adult somatic cells by protein-based reprogramming without genetic manipulation," Blood, vol. 116, no. 3, pp. 386-395, 2010.

[11] E. Yakubov, G. Rechavi, S. Rozenblatt, and D. Givol, "Reprogramming of human fibroblasts to pluripotent stem cells using mRNA of four transcription factors," Biochemical and Biophysical Research Communications, vol. 394, no. 1, pp. 189-193, 2010.

[12] R. L. Judson, J. E. Babiarz, M. Venere, and R. Blelloch, "Embryonic stem cell-specific microRNAs promote induced pluripotency," Nature Biotechnology, vol. 27, no. 5, pp. 459-461, 2009.

[13] J. R. Thonhoff, L. Ojeda, and P. Wu, "Stem cell-derived motor neurons: applications and challenges in amyotrophic lateral sclerosis," Current Stem Cell Research and Therapy, vol. 4, no. 3, pp. 178-199, 2009.

[14] L. Mazzini, F. Fagioli, R. Boccaletti et al., "Stem cell therapy in amyotrophic lateral sclerosis: a methodological approach in humans," Amyotrophic Lateral Sclerosis and Other Motor Neuron Disorders, vol. 4, no. 3, pp. 158-161, 2003.

[15] L. Mazzini, K. Mareschi, I. Ferrero et al., "Stem cell treatment in Amyotrophic Lateral Sclerosis," Journal of the Neurological Sciences, vol. 265, no. 1-2, pp. 78-83, 2008.

[16] L. Mazzini, I. Ferrero, V. Luparello et al., "Mesenchymal stem cell transplantation in amyotrophic lateral sclerosis: a phase I clinical trial," Experimental Neurology, vol. 223, no. 1, pp. 229-237, 2010.

[17] L. Mazzini, K. Mareschi, I. Ferrero et al., "Mesenchymal stromal cell transplantation in amyotrophic lateral sclerosis: a long-term safety study," Cytotherapy, vol. 14, no. 1, pp. 56-60, 2012.

[18] B. Nefussy, I. Artamonov, V. Deutsch, E. Naparstek, A. Nagler, and V. E. Drory, "Recombinant human granulocyte-colony stimulating factor administration for treating amyotrophic lateral sclerosis: a pilot study," Amyotrophic Lateral Sclerosis, vol. 11, no. 1-2, pp. 187-193, 2010.

[19] N. Cashman, L. Y. Tan, C. Krieger et al., "Pilot study of granulocyte colony stimulating factor (G-CSF)-mobilized peripheral blood stem cells in amyotrophic lateral sclerosis (ALS)," Muscle and Nerve, vol. 37, no. 5, pp. 620-625, 2008.

[20] C. Tarella, S. Rutella, F. Gualandi et al., "Consistent bone marrow-derived cell mobilization following repeated short courses of granulocytecolony-stimulating factor in patients with amyotrophic lateral sclerosis: results from a multicenter prospective trial," Cytotherapy, vol. 12, no. 1, pp. 50-59, 2010. 
[21] S. Slavin, B. G. S. Kurkalli, and D. Karussis, "The potential use of adult stem cells for the treatment of multiple sclerosis and other neurodegenerative disorders," Clinical Neurology and Neurosurgery, vol. 110, no. 9, pp. 943-946, 2008.

[22] S. Bonilla, P. Alarcón, R. Villaverde, P. Aparicio, A. Silva, and S. Martínez, "Haematopoietic progenitor cells from adult bone marrow differentiate into cells that express oligodendroglial antigens in the neonatal mouse brain," European Journal of Neuroscience, vol. 15, no. 3, pp. 575-582, 2002.

[23] S. Pluchino, A. Gritti, E. Blezer et al., "Human neural stem cells ameliorate autoimmune encephalomyelitis in non-human primates," Annals of Neurology, vol. 66, no. 3, pp. 343-354, 2009.

[24] M. Czepiel, V. Balasubramaniyan, W. Schaafsma et al., "Differentiation of induced pluripotent stem cells into functional oligodendrocytes," Glia, vol. 59, no. 6, pp. 882-892, 2011.

[25] K. P. Reekmans, J. Praet, N. de Vocht et al., "Clinical potential of intravenous neural stem cell delivery for treatment of neuroinflammatory disease in mice?" Cell Transplantation, vol. 20, no. 6, pp. 851-869, 2011.

[26] B. Yamout, R. Hourani, H. Salti et al., "Bone marrow mesenchymal stem cell transplantation in patients with multiple sclerosis: a pilot study," Journal of Neuroimmunology, vol. 227, no. 1-2, pp. 185-189, 2010.

[27] R. K. Burt, Y. Loh, B. Cohen et al., "Autologous nonmyeloablative haemopoietic stem cell transplantation in relapsing-remitting multiple sclerosis: a phase I/II study," The Lancet Neurology, vol. 8, no. 3, pp. 244-253, 2009.

[28] R. Saccardi, T. Kozak, C. Bocelli-Tyndall et al., "Autologous stem cell transplantation for progressive multiple sclerosis: update of the European Group for Blood and Marrow Transplantation autoimmune diseases working party database," Multiple Sclerosis, vol. 12, no. 6, pp. 814-823, 2006.

[29] R. A. Nash, R. Dansey, J. Storek et al., "Epstein-Barr virusassociated posttransplantation lymphoproliferative disorder after high-dose immunosuppressive therapy and autologous CD34-selected hematopoietic stem cell transplantation for severe autoimmune diseases," Biology of Blood and Marrow Transplantation, vol. 9, no. 9, pp. 583-591, 2003.

[30] J.-T. Vilquin, C. Catelain, and K. Vauchez, "Cell therapy for muscular dystrophies: advances and challenges," Current Opinion in Organ Transplantation, vol. 16, no. 6, pp. 640-649, 2011.

[31] K. Vauchez, J. P. Marolleau, M. Schmid et al., "Aldehyde dehydrogenase activity identifies a population of human skeletal muscle cells with high myogenic capacities," Molecular Therapy, vol. 17, no. 11, pp. 1948-1958, 2009.

[32] G. Ferrari, G. Cusella-De Angelis, M. Coletta et al., "Muscle regeneration by bone marrow-derived myogenic progenitors," Science, vol. 279, no. 5356, pp. 1528-1530, 1998.

[33] J. F. Lafreniere, M. C. Caron, D. Skuk, M. Goulet, A. R. Cheikh, and J. P. Tremblay, "Growth factor coinjection improves the migration potential of monkey myogenic precursors without affecting cell transplantation success," Cell Transplantation, vol. 18, no. 7, pp. 719-730, 2009.

[34] S.-W. Feng, F. Chen, J. Cao et al., "Restoration of muscle fibers and satellite cells after isogenic MSC transplantation with microdystrophin gene delivery," Biochemical and Biophysical Research Communications, vol. 419, no. 1, pp. 1-6, 2012.

[35] F. Xiong, Y. Xu, H. Zheng et al., "Microdystrophin delivery in dystrophin-deficient $(m d x)$ mice by genetically-corrected syngeneic MSCs transplantation," Transplantation Proceedings, vol. 42 , no. 7, pp. 2731-2739, 2010.
[36] M. Ikezawa, B. Cao, Z. Qu et al., "Dystrophin delivery in dystrophin-deficient DMDmdx skeletal muscle by isogenic muscle-derived stem cell transplantation," Human Gene Therapy, vol. 14, no. 16, pp. 1535-1546, 2003.

[37] E. Bachrach, S. Li, A. L. Perez et al., "Systemic delivery of human microdystrophin to regenerating mouse dystrophic muscle by muscle progenitor cells," Proceedings of the National Academy of Sciences of the United States of America, vol. 101, no. 10, pp. 3581-3586, 2004.

[38] L. Boldrin, P. S. Zammit, F. Muntoni, and J. E. Morgan, "Mature adult dystrophic mouse muscle environment does not impede efficient engrafted satellite cell regeneration and self-renewal," Stem Cells, vol. 27, no. 10, pp. 2478-2487, 2009.

[39] E. J. Gang, R. Darabi, D. Bosnakovski et al., "Engraftment of mesenchymal stem cells into dystrophin-deficient mice is not accompanied by functional recovery," Experimental Cell Research, vol. 315, no. 15, pp. 2624-2636, 2009.

[40] C. S. Kuhr, M. Lupu, and R. Storb, "Hematopoietic cell transplantation directly into dystrophic muscle fails to reconstitute satellite cells and myofibers," Biology of Blood and Marrow Transplantation, vol. 13, no. 8, pp. 886-888, 2007.

[41] A. M. Neumeyer, D. Cros, D. McKenna-Yasek et al., "Pilot study of myoblast transfer in the treatment of Becker muscular dystrophy," Neurology, vol. 51, no. 2, pp. 589-592, 1998.

[42] D. Skuk, M. Goulet, B. Roy et al., "Dystrophin expression in muscles of Duchenne muscular dystrophy patients after high-density injections of normal myogenic cells," Journal of Neuropathology and Experimental Neurology, vol. 65, no. 4, pp. 371-386, 2006.

[43] C. Zhang et al., "Therapy of Duchenne muscular dystrophy with umbilical cord blood stem cell transplantation," Zhonghua Yi Xue Yi Chuan Xue Za Zhi, vol. 22, no. 4, pp. 399-405, 2005.

[44] J. Yu, C. Zheng, X. Ren et al., "Intravenous administration of bone marrow mesenchymal stem cells benefits experimental autoimmune myasthenia gravis mice through an immunomodulatory action," Scandinavian Journal of Immunology, vol. 72, no. 3, pp. 242-249, 2010.

[45] Z. Guo, C. Zheng, Z. Chen et al., "Fetal BM-derived mesenchymal stem cells promote the expansion of human Th17 cells, but inhibit the production of Th1 cells," European Journal of Immunology, vol. 39, no. 10, pp. 2840-2849, 2009.

[46] J. X. Yu et al., "Umbilical cord mesenchymal stem cell transplantation for treatment of experimental autoimmune myasthenia gravis in rats," Zhongguo Shi Yan Xue Ye Xue Za Zhi, vol. 19, no. 3, pp. 744-748, 2011.

[47] J. R. Sheng, T. Muthusamy, B. S. Prabhakar, and M. N. Meriggioli, "GM-CSF-induced regulatory $\mathrm{T}$ cells selectively inhibit anti-acetylcholine receptor-specific immune responses in experimental myasthenia gravis," Journal of Neuroimmunology, vol. 240, pp. 65-73, 2011.

[48] J. N. Solomon, C. A. B. Lewis, B. Ajami, S. Y. Corbel, F. M. V. Rossi, and C. Krieger, "Origin and distribution of bone marrowderived cells in the central nervous system in a mouse model of amyotrophic lateral sclerosis," Glia, vol. 53, no. 7, pp. 744-753, 2006.

[49] S. Corti, F. Locatelli, C. Donadoni et al., "Wild-type bone marrow cells ameliorate the phenotype of SOD1-G93A ALS mice and contribute to CNS, heart and skeletal muscle tissues," Brain, vol. 127, no. 11, pp. 2518-2532, 2004.

[50] S. Ohnishi, H. Ito, Y. Suzuki et al., "Intra-bone marrow-bone marrow transplantation slows disease progression and prolongs 
survival in G93A mutant SOD1 transgenic mice, an animal model mouse for amyotrophic lateral sclerosis," Brain Research, vol. 1296, pp. 216-224, 2009.

[51] S. Corti, M. Nizzardo, M. Nardini et al., "Systemic transplantation of c-kit+ cells exerts a therapeutic effect in a model of amyotrophic lateral sclerosis," Human Molecular Genetics, vol. 19, no. 19, Article ID ddq293, pp. 3782-3796, 2010.

[52] E. Morita, Y. Watanabe, M. Ishimoto et al., "A novel cell transplantation protocol and its application to an ALS mouse model," Experimental Neurology, vol. 213, no. 2, pp. 431-438, 2008.

[53] C. Boucherie, S. Schäfer, P. Lavand'homme, J. M. Maloteaux, and E. Hermans, "Chimerization of astroglial population in the lumbar spinal cord after mesenchymal stem cell transplantation prolongs survival in a rat model of amyotrophic lateral sclerosis," Journal of Neuroscience Research, vol. 87, no. 9, pp. 2034-2046, 2009.

[54] S. Forostyak, P. Jendelova, M. Kapcalova, D. Arboleda, and E. Sykova, "Mesenchymal stromal cells prolong the lifespan in a rat model of amyotrophic lateral sclerosis," Cytotherapy, vol. 13, no. 9, pp. 1036-1046, 2011.

[55] H. Kim, H. Y. Kim, M. R. Choi et al., "Dose-dependent efficacy of ALS-human mesenchymal stem cells transplantation into cisterna magna in SOD1-G93A ALS mice," Neuroscience Letters, vol. 468, no. 3, pp. 190-194, 2010.

[56] C. P. Zhao, C. Zhang, S. N. Zhou et al., "Human mesenchymal stromal cells ameliorate the phenotype of SOD1-G93A ALS mice," Cytotherapy, vol. 9, no. 5, pp. 414-426, 2007.

[57] H. J. Habisch, M. Janowski, D. Binder et al., "Intrathecal application of neuroectodermally converted stem cells into a mouse model of ALS: limited intraparenchymal migration and survival narrows therapeutic effects," Journal of Neural Transmission, vol. 114, no. 11, pp. 1395-1406, 2007.

[58] A. Vercelli, O. M. Mereuta, D. Garbossa et al., "Human mesenchymal stem cell transplantation extends survival, improves motor performance and decreases neuroinflammation in mouse model of amyotrophic lateral sclerosis," Neurobiology of Disease, vol. 31, no. 3, pp. 395-405, 2008.

[59] M. Suzuki, J. McHugh, C. Tork et al., "Direct muscle delivery of GDNF with human mesenchymal stem cells improves motor neuron survival and function in a rat model of familial ALS," Molecular Therapy, vol. 16, no. 12, pp. 2002-2010, 2008.

[60] N. Ende, F. Weinstein, R. Chen, and M. Ende, "Human umbilical cord blood effect on sod mice (amyotrophic lateral sclerosis)," Life Sciences, vol. 67, no. 1, pp. 53-59, 2000.

[61] R. Chen and N. Ende, "The potential for the use of mononuclear cells from human umbilical cord blood in the treatment of amyotrophic lateral sclerosis in SOD1 mice," Journal of Medicine, vol. 31, no. 1-2, pp. 21-30, 2000.

[62] S. Garbuzova-Davis, A. E. Willing, T. Zigova et al., "Intravenous administration of human umbilical cord blood cells in a mouse model of amyotrophic lateral sclerosis: distribution, migration, and differentiation," Journal of Hematotherapy and Stem Cell Research, vol. 12, no. 3, pp. 255-270, 2003.

[63] S. Garbuzova-Davis, C. D. Sanberg, N. Kuzmin-Nichols et al., "Human umbilical cord blood treatment in a mouse model of ALS: Optimization of cell dose," PLoS One, vol. 3, no. 6, Article ID e2494, 2008.

[64] A. A. Rizvanov, A. P. Kiyasov, I. M. Gaziziov et al., "Human umbilical cord blood cells transfected with VEGF and L1CAM do not differentiate into neurons but transform into vascular endothelial cells and secrete neuro-trophic factors to support neuro-genesis-a novel approach in stem cell therapy," Neurochemistry International, vol. 53, no. 6-8, pp. 389-394, 2008.

[65] P. Bigini, P. Veglianese, G. Andriolo et al., "Intracerebroventricular administration of human umbilical cord blood cells delays disease progression in two murine models of motor neuron degeneration," Rejuvenation Research, vol. 14, no. 6, pp. 623-639, 2011.

[66] A. A. Rizvanov, D. S. Guseva, I. I. Salafutdinov et al., "Genetically modified human umbilical cord blood cells expressing vascular endothelial growth factor and fibroblast growth factor 2 differentiate into glial cells after transplantation into amyotrophic lateral sclerosis transgenic mice," Experimental Biology and Medicine, vol. 236, no. 1, pp. 91-98, 2011.

[67] S. M. Klein, S. Behrstock, J. Mchugh et al., "GDNF delivery using human neural progenitor cells in a rat model of ALS," Human Gene Therapy, vol. 16, no. 4, pp. 509-521, 2005.

[68] M. Suzuki, J. McHugh, C. Tork et al., "GDNF secreting human neural progenitor cells protect dying motor neurons, but not their projection to muscle, in a rat model of familial ALS," PLoS One, vol. 2, no. 1, article e689, 2007.

[69] L. Xu, P. Shen, T. Hazel, K. Johe, and V. E. Koliatsos, "Dual transplantation of human neural stem cells into cervical and lumbar cord ameliorates motor neuron disease in SOD1 transgenic rats," Neuroscience Letters, vol. 494, no. 3, pp. 222-226, 2011.

[70] J. Yan, L. Xu, A. M. Welsh et al., "Combined immunosuppressive agents or CD4 antibodies prolong survival of human neural stem cell grafts and improve disease outcomes in amyotrophic lateral sclerosis transgenic mice," Stem Cells, vol. 24, no. 8, pp. 1976-1985, 2006.

[71] D. H. Hwang, H. J. Lee, I. H. Park et al., "Intrathecal transplantation of human neural stem cells overexpressing VEGF provide behavioral improvement, disease onset delay and survival extension in transgenic ALS mice," Gene Therapy, vol. 16, no. 10, pp. 1234-1244, 2009.

[72] N. Souayah, K. M. Coakley, R. Chen, N. Ende, and J. J. McArdle, "Defective neuromuscular transmission in the SOD $1{ }^{\mathrm{G} 93 \mathrm{~A}}$ transgenic mouse improves after administration of human umbilical cord blood cells," Stem Cell Reviews and Reports, pp. 224-228, 2011.

[73] S. Corti, F. Locatelli, D. Papadimitriou et al., "Neural stem cells LewisX + CXCR4 + modify disease progression in an amyotrophic lateral sclerosis model," Brain, vol. 130, no. 5, pp. 1289-1305, 2007.

[74] D. Mitrečić, C. Nicaise, S. Gajović, and R. Pochet, "Distribution, differentiation, and survival of intravenously administered neural stem cells in a rat model of amyotrophic lateral sclerosis," Cell Transplantation, vol. 19, no. 5, pp. 537-548, 2010.

[75] L. J. Martin and Z. Liu, "Adult olfactory bulb neural precursor cell grafts provide temporary protection from motor neuron degeneration, improve motor function, and extend survival in amyotrophic lateral sclerosis mice," Journal of Neuropathology and Experimental Neurology, vol. 66, no. 11, pp. 1002-1018, 2007.

[76] R. López-González, P. Kunckles, and I. Velasco, “Transient recovery in a rat model of familial amyotrophic lateral sclerosis after transplantation of motor neurons derived from mouse embryonic stem cells," Cell Transplantation, vol. 18, no. 10-11, pp. 1171-1181, 2009.

[77] A. C. Lepore, J. O’Donnell, A. S. Kim et al., "Human Glialrestricted progenitor transplantation into cervical spinal cord 
of the SOD $1^{\mathrm{G} 93 \mathrm{~A}}$ mouse model of ALS," PLoS One, vol. 6, no. 10, Article ID 25968, 2011.

[78] H. Deda, M. C. Inci, A. E. Kürekçi et al., "Treatment of amyotrophic lateral sclerosis patients by autologous bone marrow-derived hematopoietic stem cell transplantation: a 1year follow-up," Cytotherapy, vol. 11, no. 1, pp. 18-25, 2009.

[79] H. R. Martinez, M. T. Gonzalez-Garza, J. E. Moreno-Cuevas, E. Caro, E. Gutierrez-Jimenez, and J. J. Segura, "Stem-cell transplantation into the frontal motor cortex in amyotrophic lateral sclerosis patients," Cytotherapy, vol. 11, no. 1, pp. 26-34, 2009.

[80] M. Blanquer, P. M. A. Espejo, F. Iniesta et al., "Bone marrow stem cell transplantation in amyotrophic lateral sclerosis: technical aspects and preliminary results from a clinical trial," Methods Find Exp Clin Pharmacol, vol. 32, supplement A, pp. 31-37, 2010.

[81] D. Karussis, C. Karageorgiou, A. Vaknin-Dembinsky et al., "Safety and immunological effects of mesenchymal stem cell transplantation in patients with multiple sclerosis and amyotrophic lateral sclerosis," Archives of Neurology, vol. 67, no. 10, pp. 1187-1194, 2010.

[82] T. Ben-Hur, O. Einstein, R. Mizrachi-Kol et al., "Transplanted multipotential neural precursor cells migrate into the inflamed white matter in response to experimental autoimmune encephalomyelitis," Glia, vol. 41, no. 1, pp. 73-80, 2003.

[83] S. Pluchino, A. Quattrini, E. Brambilla et al., "Injection of adult neurospheres induces recovery in a chronic model of multiple sclerosis," Nature, vol. 422, no. 6933, pp. 688-694, 2003.

[84] O. Einstein, Y. Friedman-Levi, N. Grigoriadis, and T. Ben-Hur, "Transplanted neural precursors enhance host brain-derived myelin regeneration," Journal of Neuroscience, vol. 29, no. 50, pp. 15694-15702, 2009.

[85] O. Einstein, N. Fainstein, I. Vaknin et al., "Neural precursors attenuate autoimmune encephalomyelitis by peripheral immunosuppression," Annals of Neurology, vol. 61, no. 3, pp. 209-218, 2007.

[86] L. S. Politi, M. Bacigaluppi, E. Brambilla et al., "Magnetic resonance-based tracking and quantification of intravenously injected neural stem cell accumulation in the brains of mice with experimental multiple sclerosis," Stem Cells, vol. 25, no. 10, pp. 2583-2592, 2007.

[87] A. Giannakopoulou, N. Grigoriadis, E. Polyzoidoua, O. Touloumi, E. Michaloudi, and G. C. Papadopoulos, "Inflammatory changes induced by transplanted neural precursor cells in a multiple sclerosis model," NeuroReport, vol. 22, no. 2, pp. 68-72, 2011.

[88] N. Muja, M. E. Cohen, J. Zhang et al., "Neural precursors exhibit distinctly different patterns of cell migration upon transplantation during either the acute or chronic phase of EAE: a serial MR imaging study," Magnetic Resonance in Medicine, vol. 65, no. 6, pp. 1738-1749, 2011.

[89] M. O. Totoiu, G. I. Nistor, T. E. Lane, and H. S. Keirstead, "Remyelination, axonal sparing, and locomotor recovery following transplantation of glial-committed progenitor cells into the MHV model of multiple sclerosis," Experimental Neurology, vol. 187, no. 2, pp. 254-265, 2004.

[90] J. L. Hardison, G. Nistor, R. Gonzalez, H. S. Keirstead, and T. E. Lane, "Transplantation of glial-committed progenitor cells into a viral model of multiple sclerosis induces remyelination in the absence of an attenuated inflammatory response," Experimental Neurology, vol. 197, no. 2, pp. 420-429, 2006.
[91] M. Aharonowiz, O. Einstein, N. Fainstein, H. Lassmann, B. Reubinoff, and T. Ben-Hur, "Neuroprotective effect of transplanted human embryonic stem cell-derived neural precursors in an animal model of multiple sclerosis," PLoS One, vol. 3, no. 9, Article ID e3145, 2008.

[92] B. Xu, P. Haviernik, L. A. Wolfraim, K. D. Bunting, and D. W. Scott, "Bone marrow transplantation combined with gene therapy to induce antigen-specific tolerance and ameliorate EAE," Molecular Therapy, vol. 13, no. 1, pp. 42-48, 2006.

[93] R. Cassiani-Ingoni, P. A. Muraro, T. Magnus et al., "Disease progression after bone marrow transplantation in a model of multiple sclerosis is associated with chronic microglial and glial progenitor response," Journal of Neuropathology and Experimental Neurology, vol. 66, no. 7, pp. 637-649, 2007.

[94] B. Van Wijmeersch, B. Sprangers, O. Rutgeerts et al., "Allogeneic bone marrow transplantation in models of experimental autoimmune encephalomyelitis: evidence for a graft-versusautoimmunity effect," Biology of Blood and Marrow Transplantation, vol. 13, no. 6, pp. 627-637, 2007.

[95] J. Croitoru-Lamoury, K. R. Williams, F. M. J. Lamoury et al., "Neural transplantation of human MSC and NT2 cells in the twitcher mouse model," Cytotherapy, vol. 8, no. 5, pp. 445-458, 2006.

[96] K. S. Carbajal, C. Schaumburg, R. Strieter, J. Kane, and T. E. Lane, "Migration of engrafted neural stem cells is mediated by CXCL12 signaling through CXCR4 in a viral model of multiple sclerosis," Proceedings of the National Academy of Sciences of the United States of America, vol. 107, no. 24, pp. 11068-11073, 2010.

[97] J. Yang, Y. Yan, B. Ciric et al., "Evaluation of bone marrow- and brain-derived neural stem cells in therapy of central nervous system autoimmunity," American Journal of Pathology, vol. 177, no. 4, pp. 1989-2001, 2010.

[98] D. Gordon, G. Pavlovska, J. B. Uney, D. C. Wraith, and N. J. Scolding, "Human mesenchymal stem cells infiltrate the spinal cord, reduce demyelination, and localize to white matter lesions in experimental autoimmune encephalomyelitis," Journal of Neuropathology and Experimental Neurology, vol. 69, no. 11, pp. 1087-1095, 2010.

[99] C. Lanza, S. Morando, A. Voci et al., "Neuroprotective mesenchymal stem cells are endowed with a potent antioxidant effect in vivo," Journal of Neurochemistry, vol. 110, no. 5, pp. 1674-1684, 2009.

[100] M. Rafei, E. Birman, K. Forner, and J. Galipeau, "Allogeneic mesenchymal stem cells for treatment of experimental autoimmune encephalomyelitis," Molecular Therapy, vol. 17, no. 10, pp. 1799-1803, 2009.

[101] M. Matysiak, M. Stasiołek, W. Orłowski et al., "Stem cells ameliorate EAE via an indoleamine 2,3-dioxygenase (IDO) mechanism," Journal of Neuroimmunology, vol. 193, no. 1-2, pp. 12-23, 2008.

[102] N. Grigoriadis, A. Lourbopoulos, R. Lagoudaki et al., "Variable behavior and complications of autologous bone marrow mesenchymal stem cells transplanted in experimental autoimmune encephalomyelitis," Experimental Neurology, vol. 230, no. 1, pp. 78-89, 2011.

[103] L. Bai, D. P. Lennon, V. Eaton et al., "Human bone marrowderived mesenchymal stem cells induce Th2-polarized immune response and promote endogenous repair in animal models of multiple sclerosis," Glia, vol. 57, no. 11, pp. 1192-1203, 2009. 
[104] Y. Barhum, S. Gai-Castro, M. Bahat-Stromza, R. Barzilay, E. Melamed, and D. Offen, "Intracerebroventricular transplantation of human mesenchymal stem cells induced to secrete neurotrophic factors attenuates clinical symptoms in a mouse model of multiple sclerosis," Journal of Molecular Neuroscience, vol. 41, no. 1, pp. 129-137, 2010.

[105] K. Takahashi, M. Prinz, M. Stagi, O. Chechneva, and H. Neumann, "TREM2-transduced myeloid precursors mediate nervous tissue debris clearance and facilitate recovery in an animal model of multiple sclerosis," PLoS Medicine, vol. 4, no. 4, article e124, pp. 675-689, 2007.

[106] T. K. Makar, D. Trisler, C. T. Bever et al., "Stem cell based delivery of IFN- $\beta$ reduces relapses in experimental autoimmune encephalomyelitis," Journal of Neuroimmunology, vol. 196, no. 1-2, pp. 67-81, 2008.

[107] T. K. Makar, C. T. Bever, I. S. Singh et al., "Brain-derived neurotrophic factor gene delivery in an animal model of multiple sclerosis using bone marrow stem cells as a vehicle," Journal of Neuroimmunology, vol. 210, no. 1-2, pp. 40-51, 2009.

[108] G. Constantin, S. Marconi, B. Rossi et al., "Adipose-derived mesenchymal stem cells ameliorate chronic experimental autoimmune encephalomyelitis," Stem Cells, vol. 27, no. 10, pp. 2624-2635, 2009.

[109] A. Woodhoo, V. Sahni, J. Gilson et al., "Schwann cell precursors: a favourable cell for myelin repair in the Central Nervous System," Brain, vol. 130, no. 8, pp. 2175-2185, 2007.

[110] M. Cristofanilli, V. K. Harris, A. Zigelbaum et al., "Mesenchymal stem cells enhance the engraftment and myelinating ability of allogeneic oligodendrocyte progenitors in dysmyelinated mice," Stem Cells and Development, vol. 20, no. 12, pp. 2065-2076, 2011.

[111] Y. Wang, J. H. Piao, E. C. Larsen, Y. Kondo, and I. D. Duncan, "Migration and remyelination by oligodendrocyte progenitor cells transplanted adjacent to focal areas of spinal cord inflammation," Journal of Neuroscience Research, vol. 89, no. 11, pp. 1737-1746, 2011.

[112] G. L. Mancardi, R. Saccardi, M. Filippi et al., "Autologous hematopoietic stem cell transplantation suppresses Gdenhanced MRI activity in MS," Neurology, vol. 57, no. 1, pp. 62-68, 2001.

[113] V. A. Rossiev, S. V. Makarov, I. Y. Alexandrova et al., "Experience with high-dose immunosuppressive therapy followed by transplantation of autologous stem hemopoietic cells in patients with multiple sclerosis," Terapevticheskii Arkhiv, vol. 74, no. 7, pp. 35-38, 2002.

[114] A. S. Fassas, J. R. Passweg, A. Anagnostopoulos et al., "Hematopoietic stem cell transplantation for multiple sclerosis: a retrospective multicenter study," Journal of Neurology, vol. 249, no. 8, pp. 1088-1097, 2002.

[115] E. Carreras, A. Saiz, P. Marín et al., "CD34 ${ }^{+}$selected autologous peripheral blood stem cell transplantation for multiple sclerosis: report of toxicity and treatment results at one year of follow-up in 15 patients," Haematologica, vol. 88, no. 3, pp. 306-314, 2003.

[116] R. A. Nash, J. D. Bowen, P. A. McSweeney et al., "High-dose immunosuppressive therapy and autologous peripheral blood stem cell transplantation for severe multiple sclerosis," Blood, vol. 102, no. 7, pp. 2364-2372, 2003.

[117] R. Saccardi, G. L. Mancardi, A. Solari et al., "Autologous HSCT for severe progressive multiple sclerosis in a multicenter trial: impact on disease activity and quality of life," Blood, vol. 105, no. 6, pp. 2601-2607, 2005.
[118] P. A. Muraro, D. C. Douek, A. Packer et al., “Thymic output generates a new and diverse TCR repertoire after autologous stem cell transplantation in multiple sclerosis patients," Journal of Experimental Medicine, vol. 201, no. 5, pp. 805-816, 2005.

[119] Y. Blanco, A. Saiz, M. Costa et al., "Evolution of brain-derived neurotrophic factor levels after autologous hematopietic stem cell transplantation in multiple sclerosis," Neuroscience Letters, vol. 380, no. 1-2, pp. 122-126, 2005.

[120] M. M. Bonab, S. Yazdanbakhsh, J. Lotfi et al., "Does mesenchymal stem cell therapy help multiple sclerosis patients? Report of a pilot study," Iranian Journal of Immunology, vol. 4, no. 1, pp. 50-57, 2007.

[121] J. Xu, B. X. Ji, L. Su et al., "Clinical outcome of autologous peripheral blood stem cell transplantation in opticospinal and conventional forms of secondary progressive multiple sclerosis in a Chinese population," Annals of Hematology, vol. 90, no. 3, pp. 343-348, 2011.

[122] M. Mohajeri, A. Farazmand, M. M. Bonab, B. Nikbin, and A. Minagar, "FOXP3 gene expression in multiple sclerosis patients pre- and post mesenchymal stem cell therapy", Iranian Journal of Allergy, Asthma and Immunology, vol. 10, no. 3, pp. 155-161, 2011.

[123] M. M. Odinak, G. N. Bisaga, and A. V. Novitskii, "Transplantation of mesenchymal stem cells in multiple sclerosis," Zhurnal Nevrologii I Psikhiatrii Imeni S.S. Korsakova, vol. 111, no. 2 part 2, pp. 72-76, 2011.

[124] P. Connick, M. Kolappan, C. Crawley et al., "Autologous mesenchymal stem cells for the treatment of secondary progressive multiple sclerosis: an open-label phase 2a proof-of-concept study," The Lancet Neurology, vol. 11, no. 2, pp. 150-156, 2012.

[125] S. Walsh et al., "Myogenic reprogramming of bone marrow derived cells in a $\mathrm{W}^{41} \mathrm{Dmd}^{m d x}$ deficient mouse model," PLoS One, vol. 6, no. 11, Article ID e27500, 2011.

[126] Z. Li, H. Y. Liu, Q. F. Lei, C. Zhang, and S. N. Li, "Improved motor function in dko mice by intravenous transplantation of bone marrow-derived mesenchymal stromal cells," Cytotherapy, vol. 13, no. 1, pp. 69-77, 2010.

[127] S. W. Feng, X. L. Lu, Z. S. Liu et al., "Dynamic distribution of bone marrow-derived mesenchymal stromal cells and change of pathology after infusing into $m d x$ mice," Cytotherapy, vol. 10, no. 3, pp. 254-264, 2008.

[128] C. Zhang, Y. Zhang, S. Feng, and X. Yao, "BM stem cell transplantation rescues pathophysiologic features of aged dystrophic $m d x$ muscle," Cytotherapy, vol. 9, no. 1, pp. 44-52, 2007.

[129] C. Dell'Agnola, Z. Wang, R. Storb et al., "Hematopoietic stem cell transplantation does not restore dystrophin expression in Duchenne muscular dystrophy dogs," Blood, vol. 104, no. 13, pp. 4311-4318, 2004.

[130] Y. Torrente, M. Belicchi, M. Sampaolesi et al., "Human circulating $\mathrm{AC}_{133^{+}}$stem cells restore dystrophin expression and ameliorate function in dystrophic skeletal muscle," Journal of Clinical Investigation, vol. 114, no. 2, pp. 182-195, 2004.

[131] A. S. de la Garza-Rodea, I. van der Velde, H. Boersma et al., "Long-term contribution of human bone marrow mesenchymal stromal cells to skeletal muscle regeneration in mice," Cell Transplantation, vol. 20, no. 2, pp. 217-231, 2011.

[132] M. Dezawa, H. Ishikawa, Y. Itokazu et al., "Developmental biology: Bone marrow stromal cells generate muscle cells and repair muscle degeneration," Science, vol. 309, no. 5732, pp. 314-317, 2005.

[133] J. Y. Lee, Z. Qu-Petersen, B. Cao et al., "Clonal isolation of muscle-derived cells capable of enhancing muscle regeneration 
and bone healing," Journal of Cell Biology, vol. 150, no. 5, pp. 1085-1100, 2000.

[134] Y. Torrente, J. P. Tremblay, F. Pisati et al., "Intraarterial injection of muscle-derived CD $34^{+} \mathrm{Sca}-1^{+}$stem cells restores dystrophin in $m d x$ mice," Journal of Cell Biology, vol. 152, no. 2, pp. 335-348, 2001.

[135] G. M. Mueller, T. O’Day, J. F. Watchko, and M. Ontell, "Effect of injecting primary myoblasts versus putative muscle-derived stem cells on mass and force generation in $m d x$ mice," Human Gene Therapy, vol. 13, no. 9, pp. 1081-1090, 2002.

[136] K. Rouger, T. Larcher, L. Dubreil et al., "Systemic delivery of allogenic muscle stem cells induces long-term muscle repair and clinical efficacy in duchenne muscular dystrophy dogs," American Journal of Pathology, vol. 179, no. 5, pp. 2501-2518, 2011.

[137] S. M. Chirieleison, J. M. Feduska, R. C. Schugar, Y. Askew, and B. M. Deasy, "Human muscle-derived cell populations isolated by differential adhesion rates: phenotype and contribution to skeletal muscle regeneration in $m d x /$ SCID mice," Tissue Engineering. Part A, vol. 18, no. 3-4, pp. 232-241, 2012.

[138] J. Meng, C. F. Adkin, S. W. Xu, F. Muntoni, and J. E. Morgan, "Contribution of human muscle-derived cells to skeletal muscle regeneration in dystrophic host mice," PLoS One, vol. 6, no. 3, Article ID e17454, 2011.

[139] S. E. Berry, J. Liu, E. J. Chaney, and S. J. Kaufman, "Multipotential mesoangioblast stem cell therapy in the $m d x /$ utrn-/mouse model for Duchenne muscular dystrophy," Regenerative Medicine, vol. 2, no. 3, pp. 275-288, 2007.

[140] C. Sciorati, B. G. Galvez, S. Brunelli et al., "Ex vivo treatment with nitric oxide increases mesoangioblast therapeutic efficacy in muscular dystrophy," Journal of Cell Science, vol. 119, no. 24, pp. 5114-5123, 2006.

[141] B. G. Galvez, M. Sampaolesi, S. Brunelli et al., "Complete repair of dystrophic skeletal muscle by mesoangioblasts with enhanced migration ability," Journal of Cell Biology, vol. 174, no. 2, pp. 231-243, 2006.

[142] M. Sampaolesi, Y. Torrente, A. Innocenzi et al., "Cell therapy of $\alpha$-sarcoglycan null dystrophic mice through intra-arterial delivery of mesoangioblasts," Science, vol. 301, no. 5632, pp. 487-492, 2003.

[143] M. Sampaolesi, S. Blot, G. D’Antona et al., "Mesoangioblast stem cells ameliorate muscle function in dystrophic dogs," Nature, vol. 444, no. 7119, pp. 574-579, 2006.

[144] A. J. Beck, J. M. Vitale, Q. Zhao et al., "Differential requirement for utrophin in the induced pluripotent stem cell correction of muscle versus fat in muscular dystrophy mice," PLoS One, vol. 6, no. 5, Article ID e20065, 2011.

[145] R. Darabi, W. Pan, D. Bosnakovski, J. Baik, M. Kyba, and R. C. R. Perlingeiro, "Functional myogenic engraftment from mouse iPS cells," Stem Cell Reviews and Reports, pp. 948-957, 2011.

[146] Y. Mizuno, H. Chang, K. Umeda et al., "Generation of skeletal muscle stem/progenitor cells from murine induced pluripotent stem cells," FASEB Journal, vol. 24, no. 7, pp. 2245-2253, 2010.

[147] Y. W. Eom, J. E. Lee, M. S. Yang et al., "Effective myotube formation in human adipose tissue-derived stem cells expressing dystrophin and myosin heavy chain by cellular fusion with mouse C2C12 myoblasts," Biochemical and Biophysical Research Communications, vol. 408, no. 1, pp. 167-173, 2011.

[148] N. M. Vieira, E. Zucconi, C. R. Bueno et al., "Human multipotent mesenchymal stromal cells from distinct sources show different in vivo potential to differentiate into muscle cells when injected in dystrophic mice," Stem Cell Reviews and Reports, vol. 6, no. 4, pp. 560-566, 2010.

[149] S. Goudenege, D. F. Pisani, B. Wdziekonski et al., "Enhancement of myogenic and muscle repair capacities of human adipose-derived stem cells with forced expression of MyoD," Molecular Therapy, vol. 17, no. 6, pp. 1064-1072, 2009.

[150] N. M. Vieira, C. R. Bueno, V. Brandalise et al., "SJL dystrophic mice express a significant amount of human muscle proteins following systemic delivery of human adipose-derived stromal cells without immunosuppression," Stem Cells, vol. 26, no. 9, pp. 2391-2398, 2008.

[151] Y. Liu, X. Yan, Z. Sun et al., "Flk-1+ adipose-derived mesenchymal stem cells differentiate into skeletal muscle satellite cells and ameliorate muscular dystrophy in $m d x$ Mice," Stem Cells and Development, vol. 16, no. 5, pp. 695-706, 2007.

[152] A. M. Rodriguez, D. Pisani, C. A. Dechesne et al., "Transplantation of a multipotent cell population from human adipose tissue induces dystrophin expression in the immunocompetent $m d x$ mouse," Journal of Experimental Medicine, vol. 201, no. 9, pp. 1397-1405, 2005.

[153] K. L. Pellegrini and M. W. Beilharz, "The survival of myoblasts after intramuscular transplantation is improved when fewer cells are injected," Transplantation, vol. 91, no. 5, pp. 522-526, 2011.

[154] J. Rousseau, N. Dumont, C. Lebel et al., "Dystrophin expression following the transplantation of normal muscle precursor cells protects $m d x$ muscle from contraction-induced damage," Cell Transplantation, vol. 19, no. 5, pp. 589-596, 2010.

[155] S. Carnio, E. Serena, C. A. Rossi, P. De Coppi, N. Elvassore, and L. Vitiello, "Three-dimensional porous scaffold allows longterm wild-type cell delivery in dystrophic muscle," Journal of Tissue Engineering and Regenerative Medicine, vol. 5, no. 1, pp. 1-10, 2011.

[156] A. L. Perez, E. Bachrach, B. M. W. Illigens et al., "CXCR4 enhances engraftment of muscle progenitor cells," Muscle and Nerve, vol. 40, no. 4, pp. 562-572, 2009.

[157] X. Gerard, L. Vignaud, S. Charles et al., "Real-time monitoring of cell transplantation in mouse dystrophic muscles by a secreted alkaline phosphatase reporter gene," Gene Therapy, vol. 16, no. 6, pp. 815-819, 2009.

[158] M. Bouchentouf, B. F. Benabdallah, P. Mills, and J. P. Tremblay, "Exercise improves the success of myoblast transplantation in $m d x$ mice," Neuromuscular Disorders, vol. 16, no. 8, pp. 518-529, 2006.

[159] E. Bachrach, A. L. Perez, Y. H. Choi et al., "Muscle engraftment of myogenic progenitor cells following intraarterial transplantation," Muscle and Nerve, vol. 34, no. 1, pp. 44-52, 2006.

[160] B. F. Benabdallah, M. Bouchentouf, and J. P. Tremblay, "Improved success of myoblast transplantation in $m d x$ mice by blocking the myostatin signal," Transplantation, vol. 79, no. 12, pp. 1696-1702, 2005.

[161] T. F. Lee-Pullen, A. L. Bennett, M. W. Beilharz, M. D. Grounds, and L. M. Sammels, "Superior survival and proliferation after transplantation of myoblasts obtained from adult mice compared with neonatal mice," Transplantation, vol. 78, no. 8, pp. 1172-1176, 2004.

[162] M. Bouchentouf, B. F. Benabdallah, and J. P. Tremblay, "Myoblast survival enhancement and transplantation success improvement by heat-shock treatment in $m d x$ mice," Transplantation, vol. 77, no. 9, pp. 1349-1356, 2004.

[163] G. P. Kobinger, J. P. Louboutin, E. R. Barton, H. L. Sweeney, and J. M. Wilson, "Correction of the dystrophic phenotype by in vivo 
targeting of muscle progenitor cells," Human Gene Therapy, vol. 14, no. 15, pp. 1441-1449, 2003.

[164] E. El Fahime, M. Bouchentouf, B. F. Benabdallah et al., "Tubulyzine, a novel tri-substituted triazine, prevents the early cell death of transplanted myogenic cells and improves transplantation success," Biochemistry and Cell Biology, vol. 81, no. 2, pp. 81-90, 2003.

[165] R. J. Jankowski, B. M. Deasy, B. Cao, C. Gates, and J. Huard, “The role of CD34 expression and cellular fusion in the regeneration capacity of myogenic progenitor cells," Journal of Cell Science, vol. 115, no. 22, pp. 4361-4374, 2002.

[166] M. H. Parker, C. Kuhr, S. J. Tapscott, and R. Storb, "Hematopoietic cell transplantation provides an immune-tolerant platform for myoblast transplantation in dystrophic dogs," Molecular Therapy, vol. 16, no. 7, pp. 1340-1346, 2008.

[167] S. Yang, T. Laumonier, and J. Menetrey, "Heat shock pretreatment enhances porcine myoblasts survival after autotransplantation in intact skeletal muscle," Science in China, Series C, vol. 50, no. 4, pp. 438-446, 2007.

[168] R. Fakhfakh, A. Michaud, and J. P. Tremblay, "Blocking the myostatin signal with a dominant negative receptor improves the success of human myoblast transplantation in dystrophic mice," Molecular Therapy, vol. 19, no. 1, pp. 204-210, 2011.

[169] B. F. Benabdallah, M. Bouchentouf, J. Rousseau, and J. P. Tremblay, "Overexpression of follistatin in human myoblasts increases their proliferation and differentiation, and improves the graft success in SCID mice," Cell Transplantation, vol. 18, no. 7, pp. 709-718, 2009.

[170] R. Benchaouir, M. Meregalli, A. Farini et al., "Restoration of human dystrophin following transplantation of exon-skippingengineered DMD patient stem cells into dystrophic mice," Cell Stem Cell, vol. 1, no. 6, pp. 646-657, 2007.

[171] P. Mills, J. C. Dominique, J. F. Lafrenière, M. Bouchentouf, and J. P. Tremblay, "A synthetic mechano growth factor E peptide enhances myogenic precursor cell transplantation success," American Journal of Transplantation, vol. 7, no. 10, pp. 2247-2259, 2007.

[172] S. P. Quenneville, P. Chapdelaine, D. Skuk et al., "Autologous transplantation of muscle precursor cells modified with a lentivirus for muscular dystrophy: human cells and primate models," Molecular Therapy, vol. 15, no. 2, pp. 431-438, 2007.

[173] Ç. Kocaefe, D. Balci, B. B. Hayta, and A. Can, "Reprogramming of human umbilical cord stromal mesenchymal stem cells for myogenic differentiation and muscle repair," Stem Cell Reviews and Reports, vol. 6, no. 4, pp. 512-522, 2010.

[174] V. A. Nunes, N. Cavaçana, M. Canovas, B. E. Strauss, and M. Zatz, "Stem cells from umbilical cord blood differentiate into myotubes and express dystrophin in vitro only after exposure to in vivo muscle environment," Biology of the Cell, vol. 99, no. 4, pp. 185-186, 2007.

[175] J. Meng, C. F. Adkin, V. Arechavala-Gomeza, L. Boldrin, F. Muntoni, and J. E. Morgan, "The contribution of human synovial stem cells to skeletal muscle regeneration," Neuromuscular Disorders, vol. 20, no. 1, pp. 6-15, 2010.

[176] C. De Bari, F. Dell'Accio, F. Vandenabeele, J. R. Vermeesch, J. M. Raymackers, and F. P. Luyten, "Skeletal muscle repair by adult human mesenchymal stem cells from synovial membrane," Journal of Cell Biology, vol. 160, no. 6, pp. 909-918, 2003.

[177] E. Stillwell, J. Vitale, Q. Zhao et al., "Blastocyst injection of wild type embryonic stem cells induces global corrections in $m d x$ mice," PLoS One, vol. 4, no. 3, Article ID e4759, 2009.
[178] S. Bhagavati and W. Xu, "Generation of skeletal muscle from transplanted embryonic stem cells in dystrophic mice," Biochemical and Biophysical Research Communications, vol. 333, no. 2, pp. 644-649, 2005.

[179] R. Darabi, J. Baik, M. Clee, M. Kyba, R. Tupler, and R. C. R. Perlingeiro, "Engraftment of embryonic stem cell-derived myogenic progenitors in a dominant model of muscular dystrophy," Experimental Neurology, vol. 220, no. 1, pp. 212-216, 2009.

[180] S. Corti, S. Strazzer, R. Del Bo et al., "A subpopulation of murine bone marrow cells fully differentiates along the myogenic pathway and participates in muscle repair in the $m d x$ dystrophic mouse," Experimental Cell Research, vol. 277, no. 1, pp. 74-85, 2002.

[181] H. Shao, B. Chen, and M. Tao, "Skeletal myogenesis by human primordial germ cell-derived progenitors," Biochemical and Biophysical Research Communications, vol. 378, no. 4, pp. 750-754, 2009.

[182] I. Kerkis, C. E. Ambrosio, A. Kerkis et al., "Early transplantation of human immature dental pulp stem cells from baby teeth to golden retriever muscular dystrophy (GRMD) dogs: local or systemic?" Journal of Translational Medicine, vol. 6, article no. 35, 2008.

[183] N. Hirt-Burri, A. S. De Buys Roessingh, C. Scaletta et al., "Human muscular fetal cells: a potential cell source for muscular therapies," Pediatric Surgery International, vol. 24, no. 1, pp. 37-47, 2008.

[184] J. Chan, S. N. Waddington, K. O’Donoghue et al., "Widespread distribution and muscle differentiation of human fetal mesenchymal stem cells after intrauterine transplantation in dystrophic $m d x$ mouse," Stem Cells, vol. 25, no. 4, pp. 875-884, 2007.

[185] J. Chan, K. O’Donoghue, M. Gavina et al., "Galectin-1 induces skeletal muscle differentiation in human fetal mesenchymal stem cells and increases muscle regeneration," Stem Cells, vol. 24, no. 8, pp. 1879-1891, 2006.

[186] R. E. Bittner, C. Schöfer, K. Weipoltshammer et al., "Recruitment of bone-marrow-derived cells by skeletal and cardiac muscle in adult dystrophic mdx mice," Anatomy and Embryology, vol. 199, no. 5, pp. 391-396, 1999.

[187] Y. Torrente, M. Belicchi, C. Marchesi et al., "Autologous transplantation of muscle-derived $\mathrm{CD}_{133^{+}}$stem cells in Duchenne muscle patients," Cell Transplantation, vol. 16, no. 6, pp. 563-577, 2007. 


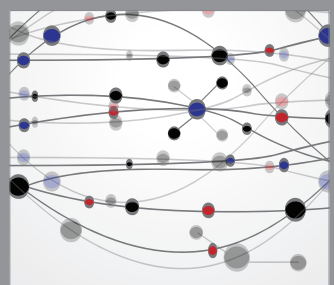

The Scientific World Journal
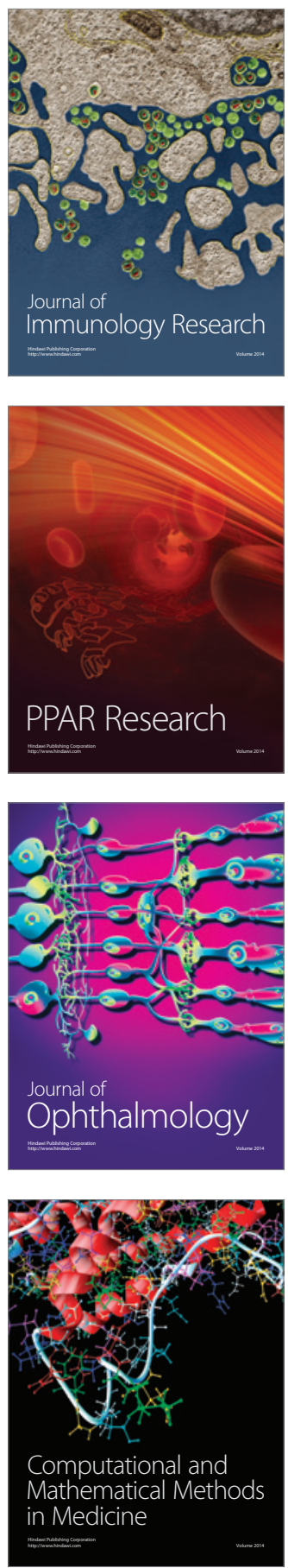

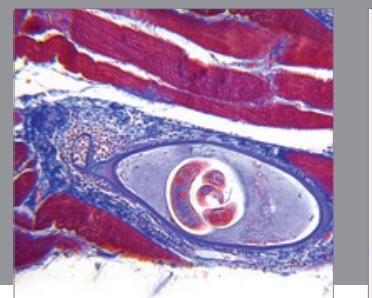

Gastroenterology

Research and Practice
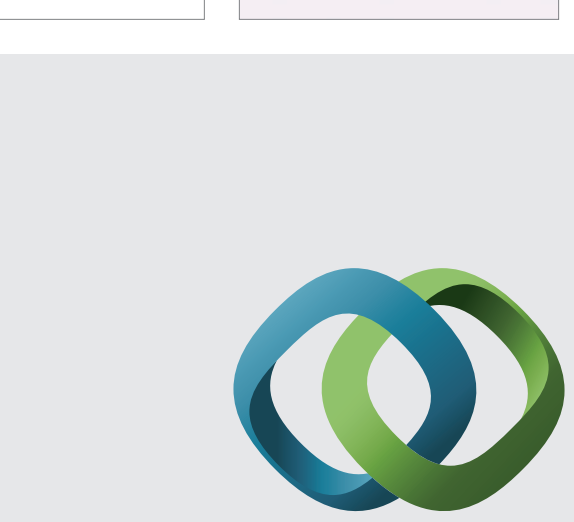

\section{Hindawi}

Submit your manuscripts at

http://www.hindawi.com
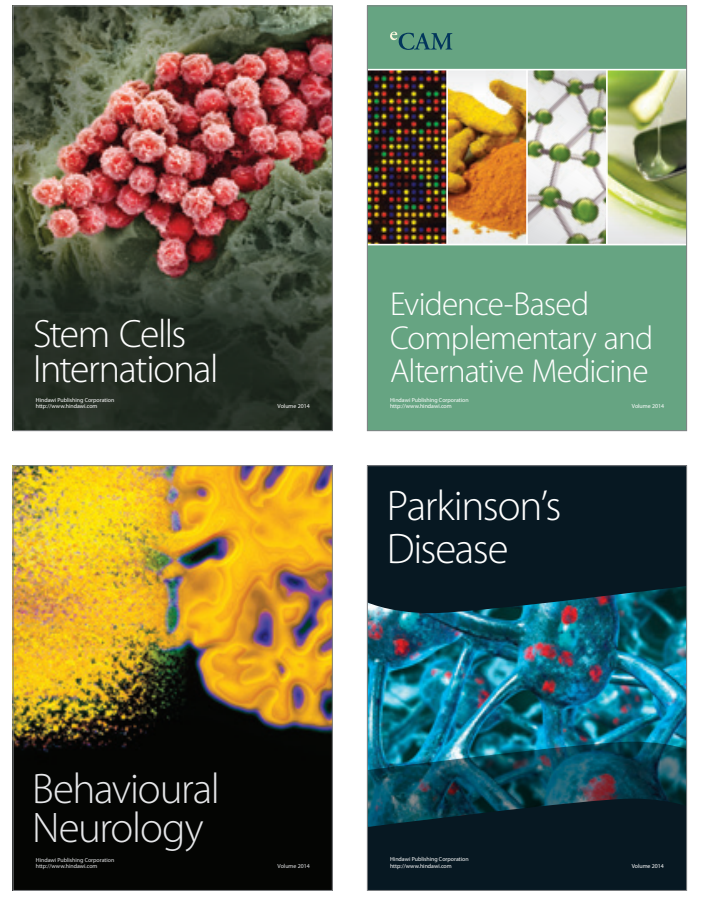
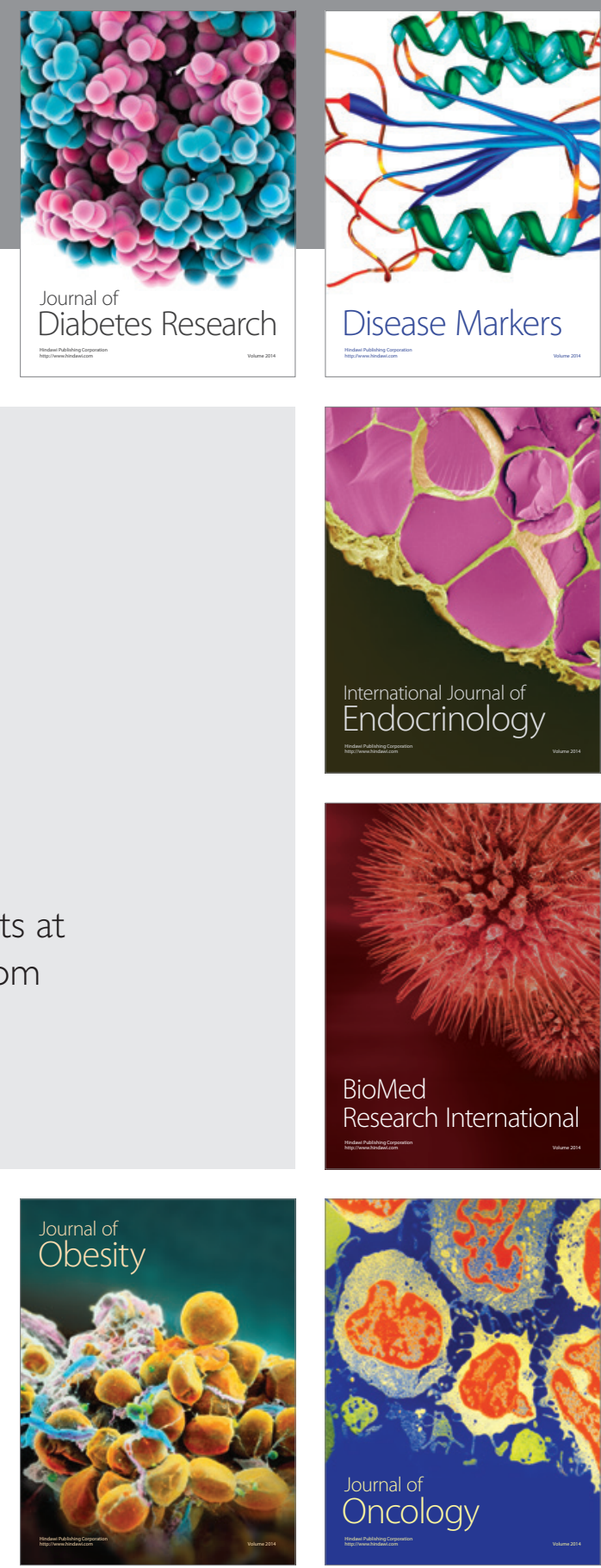

Disease Markers
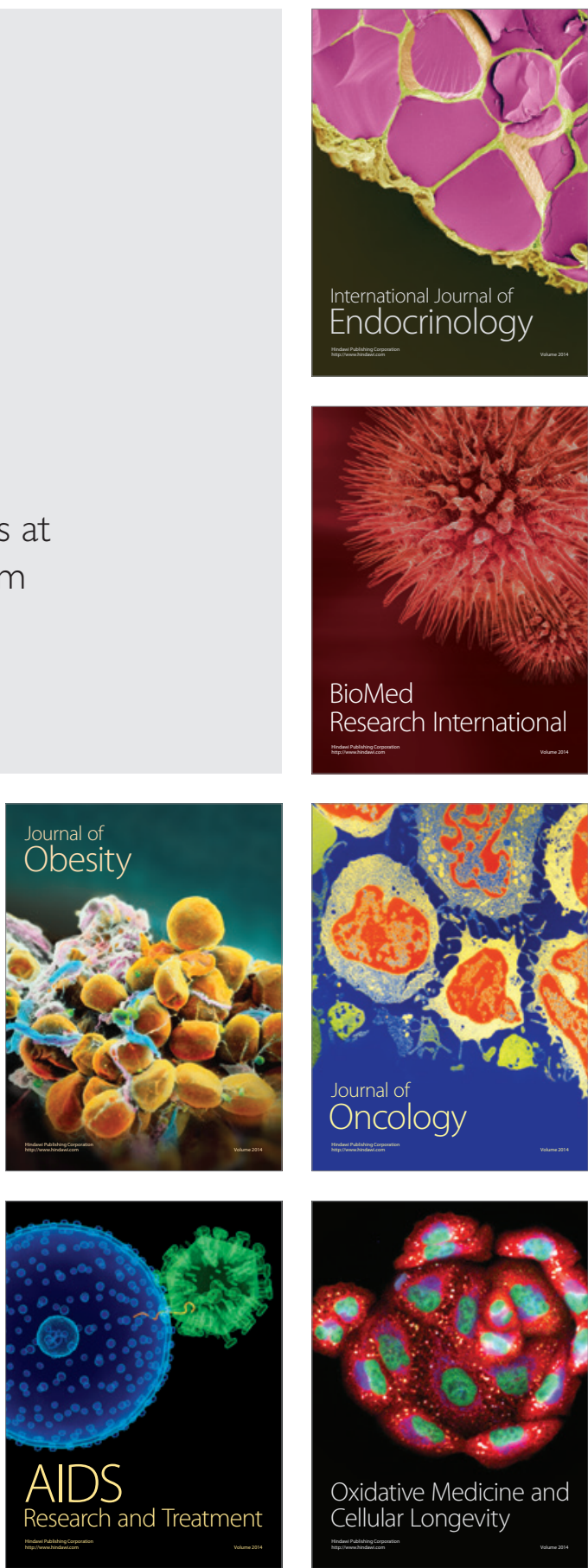